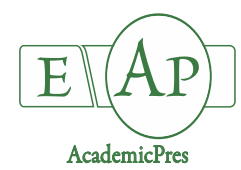

Santana SR et al. (2020)
Notulae Botanicae Horti Agrobotanici Cluj-Napoca 48(4):2198-2214
DOI:10.15835/48412043
Research Article

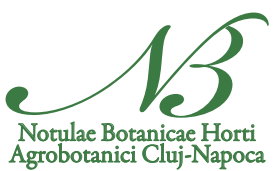

\title{
Analysis of agronomic and chemical-nutritional variability of fruits in Amazon germplasm of Capsicum chinense
}

\author{
Santina R. SANTANA ${ }^{1 *}$, Derly J. H. da SILVA², Leonardo L. \\ BHERING ${ }^{3}$, Ronaldo S. GOMES ${ }^{2}$, Renato D. S. ROSADO ${ }^{2}$, \\ Paula C. C. LIMA $^{2}$ \\ ${ }^{I}$ Federal University of Rondônia, Fishery Engineering Department, Presidente Médici, RO, \\ Brazil; santina@unir.br ('corresponding author) \\ ${ }^{2}$ Federal University of Viçosa, Department of Agronomy, Viçosa, MG, Brazil; derly@ufv.br; \\ ronaldo.s.gomes@ufv.br; renato.rosado@ufv.br;Paula.c.lima@ufv.br \\ ${ }^{3}$ Federal University of Viçosa, Department of General Biology, Viçosa, MG, Brazil; leonardo.bhering@ufv.br
}

\begin{abstract}
Fruits of Capsicum chinense, a native species of Amazon Basin, express high levels of bioactive components such as vitamin $\mathrm{C}$ and carotenoids; some of them with pronounced pro-vitamin $\mathrm{A}$ activity such as $\beta$-carotene, which confers high economic potential to this species. The characterization of $C$. chinense germplasm helps in its management and conservation. Therefore, this practice is considered crucial for the identification of genotypes with superior characteristics, especially in relation to agronomic aspects and chemical-nutritional characteristics of fruits. This study aimed to characterize $55 \mathrm{C}$. chinense accessions collected from the Brazilian Amazon in terms of their agronomic and chemical-nutritional descriptors aiming to identify superior genotypes for these traits. The characterization was performed in a completely randomized design with 5 replications in non-heated environment. There was significant difference for all descriptors, confirming the variability among accessions. High heritability estimates for descriptors, such as fruit yield (95.1\%) and vitamin $\mathrm{C}$ content of fruit (92.4\%), was found to be associated with high $\mathrm{CVg} / \mathrm{CVe}$ ratios of these traits, indicating a favorable condition for the selection of superior genotypes for these characteristics. A considerable part of the accessions expressed averages higher than the checks, notably for the fruit yield and the content of vitamin C. The cluster analysis resulted in the formation of 11 groups, corroborating the high variability of accessions for the agronomic and chemical-nutritional aspects of fruits. The evaluated $C$. chinense germplasm thus expressed high fruit yield and vitamin $\mathrm{C}$ content in the fruits, which makes it a promising source for the selection of superior genotypes.
\end{abstract}

Keywords: characterization; conservation; pepper; breeding; vitamin C 


\section{Introduction}

Capsicum spp. peppers belong to the Solanaceae family, and they are much appreciated vegetables worldwide (Rodrigues et al., 2016). According to FAOSTAT (2018), the countries with greater production of capsicum peppers in the world in 2016 included Vietnam (216,432 t), Indonesia (82,167 t), India (55,000 t), Brazil (54,425 t), and Sri Lanka (28,901 t). In Brazil, pepper cultivation is performed in all regions, and the states with the highest production include Minas Gerais, Goiás, Sao Paulo, Ceará, and Rio Grande do Sul (Carvalho et al., 2006). The most appreciated peppers in Brazil are the C. frutescens, C. baccatum, and the varieties of $C$. chinense (such as the well-known 'Biquinho') (Rufino and Penteado, 2006).

Peppers are one of the most important spices in the world, owing to their intrinsic characteristics such as the aroma and color, in addition to being a source of minerals and vitamins such as vitamins $\mathrm{A}, \mathrm{C}$, and (Bosland and Votava, 2000). They are considered as a functional food regarding to their antioxidant properties (Pinto et al., 2013). In food industry, these peppers are used to preparing condiments, sauces, powder products, paprika, vinegar tanning, jellies, and for canning (Chunab et al., 2011; Pinto et al., 2013; Jäger and Amaya, 2013).

Capsicum chinense, which is native to the Brazilian Amazon, is considered to be the most Brazilian of all species within this genus (Reifschneider, 2000). It expresses great variability in the diversity of its shapes and colors of fruits, which are also very spicy and aromatic (Carvalho et al., 2006); these properties favor the selection of promising parents for breeding programs of the species. The consumption, cultivation, and the conservation of this species in the Amazon region is mainly practiced by the traditional communities such as indigenous, riverside, and small farmers, who have been traditionally trading the fruits of this species in the local markets either in the fresh state or in the form of artisanal preserves.

The characterization study is of great importance as it provides wide information about the germplasm for application in plant breeding programs. According to Burle and Oliveira (2010), it is an essential activity in the management of germplasm collections and involves collecting data to describe, identify, and differentiate accessions. This activity is performed based on the qualitative and quantitative observations of several differentiable characters, such as the morphological descriptors.

The use of multivariate statistical procedures in germplasm characterization studies is important because one can then consider the correlations among the characters, which in turn allows identifying the sources of genetic variability and the importance of each evaluated character in relation to the total genetic divergence (Moura et al., 1999). This strategy is also important to identify promising parents, targeting the attainment of hybrids with higher heterotic vigor (Cruz et al., 2012).

This work had as objectives: a) to characterize 55 accessions of $C$. chinense from the Brazilian Amazon regarding the agronomic characteristics and chemical-nutritional aspects of the fruits, in order to identify promising accessions for these characteristics for use in a breeding program and b) analyze the variability of accessions.

\section{Materials and Methods}

\section{Germplasm and origin off collect}

We evaluated 55 C. chinense accessions (Table 1), collected from the local markets and vegetable gardens from 9 cities of the state of Rondônia which belongs to Brazilian-legal Amazon area. Two of these genotypes are commercially grown and comprise of the varieties 'Biquinho vermelho' and 'Biquinho amarelo'. The collected genotypes were identified with their passport data and introduced in the collection of $C$. chinense maintained by the Vegetable Germplasm Bank of UFV, (BGH-UFV).

The state of Rondônia occupies an area of $237590,547 \mathrm{~km}^{2}$ and is located in the Legal Amazon of the northern Brazil (Figure 1). The prevailing climate in this state throughout the year is humid and warm tropical. 
According to the Köppen climate classification (1948), Rondônia has an Aw-Tropical Rainy Climate, with average temperatures of $>18^{\circ} \mathrm{C}$ in the coldest month and a well-defined dry season during the winters. The annual temperature in the state varies between $25^{\circ} \mathrm{C}$ to $27^{\circ} \mathrm{C}$, while the maximum temperatures vary between $31^{\circ} \mathrm{C}$ to $35^{\circ} \mathrm{C}$, and the minimum temperature between $17^{\circ} \mathrm{C}$ to $23^{\circ} \mathrm{C}$ (Arruda, 2012). The typical vegetation in the state of Rondônia consists of the Amazon rainforest with some savanna patches.

Table 1. The origin of $C$. chinense genotypes collected and introduced at BGH-UFV, Viçosa, 2019

\begin{tabular}{|c|c|c|c|c|c|}
\hline Accessions & $\begin{array}{l}\text { Place of } \\
\text { collect }\end{array}$ & Coordinates & Accessions & Place of collect & Coordinates \\
\hline BGH 8287 & Feira-Cacoal & $11^{\circ} 26^{\prime} 27.20^{\prime \prime} \mathrm{S} 61^{\circ} 26^{\prime} 41.03^{\prime \prime} \mathrm{O}$ & BGH 8322 & Feira-Cacoal & $11^{\circ} 25^{\prime} 59.71^{\prime \prime} \mathrm{S} 61^{\circ} 27^{\prime} 50.97^{\prime \prime} \mathrm{O}$ \\
\hline BGH 8288 & Feira-Cacoal & $11^{\circ} 26^{\prime} 27.20^{\prime \prime} \mathrm{S} 61^{\circ} 26^{\prime} 41.03^{\prime \prime} \mathrm{O}$ & BGH 8324 & Feira-Cacoal & $11^{\circ} 25^{\prime} 59.71^{\prime \prime} \mathrm{S} 61^{\circ} 27^{\prime} 50.97^{\prime \prime} \mathrm{O}$ \\
\hline BGH 8290 & Feira-Cacoal & $11^{\circ} 26^{\prime} 27.20^{\prime \prime} \mathrm{S} 61^{\circ} 26^{\prime} 41.03^{\prime \prime} \mathrm{O}$ & BGH 8325 & Feira-Cacoal & $11^{\circ} 25^{\prime} 59.71^{\prime \prime} \mathrm{S} 61^{\circ} 27^{\prime} 50.97^{\prime \prime} \mathrm{O}$ \\
\hline BGH 8291 & Feira-Cacoal & $11^{\circ} 26^{\prime} 27.20^{\prime \prime} \mathrm{S} 61^{\circ} 26^{\prime} 41.03^{\prime \prime} \mathrm{O}$ & BGH 8326 & Feira-Cacoal & $11^{\circ} 25^{\prime} 59.71^{\prime \prime} \mathrm{S} 61^{\circ} 27^{\prime} 50.97^{\prime \prime} \mathrm{O}$ \\
\hline BGH 8292 & Feira-Cacoal & $11^{\circ} 26^{\prime} 27.20^{\prime \prime} \mathrm{S} 61^{\circ} 26^{\prime} 41.03^{\prime \prime} \mathrm{O}$ & BGH 8327 & Feira-Cacoal & $11^{\circ} 25^{\prime} 59.71^{\prime \prime} \mathrm{S} 61^{\circ} 27^{\prime} 50.97^{\prime \prime} \mathrm{O}$ \\
\hline BGH 8293 & Feira-Cacoal & $11^{\circ} 26^{\prime} 27.20^{\prime \prime} \mathrm{S} 61^{\circ} 26^{\prime} 41.03^{\prime \prime} \mathrm{O}$ & BGH 8328 & Feira-Cacoal & $11^{\circ} 25^{\prime} 59.71^{\prime \prime} \mathrm{S} 61^{\circ} 27^{\prime} 50.97^{\prime \prime} \mathrm{O}$ \\
\hline BGH 8296 & Feira-Cacoal & $11^{\circ} 26^{\prime} 27.20^{\prime \prime} \mathrm{S} 61^{\circ} 26^{\prime} 41.03^{\prime \prime} \mathrm{O}$ & BGH 8329 & Feira-Cacoal & $11^{\circ} 26^{\prime} 27.20^{\prime \prime} \mathrm{S} 61^{\circ} 26^{\prime} 41.03^{\prime \prime} \mathrm{O}$ \\
\hline BGH 8297 & Feira-Cacoal & $11^{\circ} 26^{\prime} 27.20^{\prime \prime} \mathrm{S} 61^{\circ} 26^{\prime} 41.03^{\prime \prime} \mathrm{O}$ & BGH 8330 & Feira-Cacoal & $11^{\circ} 26^{\prime} 27.20^{\prime \prime} \mathrm{S} 61^{\circ} 26^{\prime} 41.03^{\prime \prime} \mathrm{O}$ \\
\hline BGH 8298 & Feira-Cacoal & $11^{\circ} 26^{\prime} 27.20^{\prime \prime}$ S 6 6126'41.03" O & BGH 8333 & Feira-Cacoal & $11^{\circ} 26^{\prime} 27.20^{\prime \prime} \mathrm{S} 61^{\circ} 26^{\prime} 41.03^{\prime \prime} \mathrm{O}$ \\
\hline BGH 8299 & Feira-Cacoal & $11^{\circ} 26^{\prime} 27.20^{\prime \prime}$ S 6126'41.03" O & BGH 8338 & Feira-Cacoal & $11^{\circ} 25^{\prime} 59.71^{\prime \prime} \mathrm{S} 61^{\circ} 27^{\prime} 50.97^{\prime \prime} \mathrm{O}$ \\
\hline BGH 8300 & Feira-Cacoal & $11^{\circ} 26^{\prime} 27.20^{\prime \prime} \mathrm{S} 61^{\circ} 26^{\prime} 41.03^{\prime \prime} \mathrm{O}$ & BGH 8339 & Feira-Cacoal & $11^{\circ} 25^{\prime} 59.71^{\prime \prime} \mathrm{S} 61^{\circ} 27^{\prime} 50.97^{\prime \prime} \mathrm{O}$ \\
\hline BGH 8301 & Feira-Cacoal & $11^{\circ} 26^{\prime} 27.20^{\prime \prime} \mathrm{S} 61^{\circ} 26^{\prime} 41.03^{\prime \prime} \mathrm{O}$ & BGH 8289 & Cacoal & $11^{\circ} 26^{\prime} 46.38^{\prime \prime} \mathrm{S} 61^{\circ} 26^{\prime} 53.35^{\prime \prime} \mathrm{O}$ \\
\hline BGH 8302 & Feira-Cacoal & $11^{\circ} 25^{\prime} 59.71^{\prime \prime} \mathrm{S} 61^{\circ} 27^{\prime} 50.97^{\prime \prime} \mathrm{O}$ & BGH 8314 & $\begin{array}{l}\text { São Fco do } \\
\text { Guaporé }\end{array}$ & $12^{\circ} 03^{\prime} 57.14^{\prime \prime} \mathrm{S} 63^{\circ} 34^{\prime} 10.48^{\prime \prime} \mathrm{O}$ \\
\hline BGH 8303 & Feira-Cacoal & $11^{\circ} 25^{\prime} 59.71^{\prime \prime} \mathrm{S} 61^{\circ} 27^{\prime} 50.97^{\prime \prime} \mathrm{O}$ & BGH 8335 & $\begin{array}{l}\text { Novo Horizonte } \\
\text { D'Oeste }\end{array}$ & $11^{\circ} 43^{\prime} 28.60^{\prime \prime} \mathrm{S} 62^{\circ} 02^{\prime} 32.02^{\prime \prime} \mathrm{O}$ \\
\hline BGH 8304 & Feira-Cacoal & $11^{\circ} 25^{\prime} 59.71^{\prime \prime} \mathrm{S} 61^{\circ} 27^{\prime} 50.97^{\prime \prime} \mathrm{O}$ & BGH 8336 & $\begin{array}{l}\text { Novo Horizonte } \\
\text { D'Oeste }\end{array}$ & $11^{\circ} 43^{\prime} 28.60^{\prime \prime} \mathrm{S} 62^{\circ} 02^{\prime} 32.02^{\prime \prime} \mathrm{O}$ \\
\hline BGH 8305 & Feira-Cacoal & $11^{\circ} 25^{\prime} 59.71^{\prime \prime} \mathrm{S} 61^{\circ} 27^{\prime} 50.97^{\prime \prime} \mathrm{O}$ & BGH 8295 & $\begin{array}{l}\text { Novo Horizonte } \\
\text { D'Oeste }\end{array}$ & $11^{\circ} 43^{\prime} 28.60^{\prime \prime} \mathrm{S} 62^{\circ} 02^{\prime} 32.02^{\prime \prime} \mathrm{O}$ \\
\hline BGH 8306 & Feira-Cacoal & $11^{\circ} 25^{\prime} 59.71^{\prime \prime} \mathrm{S} 61^{\circ} 27^{\prime} 50.97^{\prime \prime} \mathrm{O}$ & BGH 8315 & $\begin{array}{l}\text { Novo Horizonte } \\
\text { D'Oeste }\end{array}$ & $11^{\circ} 43^{\prime} 26.71^{\prime \prime}$ S 615 59'55.04" O \\
\hline BGH 8307 & Feira-Cacoal & $11^{\circ} 25^{\prime} 59.71^{\prime \prime} \mathrm{S} 61^{\circ} 27^{\prime} 50.97^{\prime \prime} \mathrm{O}$ & BGH 8316 & $\begin{array}{l}\text { Novo Horizonte } \\
\text { D'Oeste }\end{array}$ & $11^{\circ} 43^{\prime} 26.71^{\prime \prime} \mathrm{S} 61^{\circ} 59^{\prime} 55.04^{\prime \prime} \mathrm{O}$ \\
\hline BGH 8308 & Feira-Cacoal & $11^{\circ} 25^{\prime} 59.71^{\prime \prime} \mathrm{S} 61^{\circ} 27^{\prime} 50.97^{\prime \prime} \mathrm{O}$ & BGH 8317 & $\begin{array}{l}\text { Novo Horizonte } \\
\text { D'Oeste }\end{array}$ & $11^{\circ} 43^{\prime} 26.71^{\prime \prime} \mathrm{S} 61^{\circ} 59^{\prime} 55.04^{\prime \prime} \mathrm{O}$ \\
\hline BGH 8309 & Feira-Cacoal & $11^{\circ} 25^{\prime} 59.71^{\prime \prime} \mathrm{S} 61^{\circ} 27^{\prime} 50.97^{\prime \prime} \mathrm{O}$ & BGH 8294 & $\begin{array}{l}\text { Novo Horizonte } \\
\text { D'Oeste }\end{array}$ & $11^{\circ} 43^{\prime} 28.60^{\prime \prime} \mathrm{S} 62^{\circ} 02^{\prime} 32.02^{\prime \prime} \mathrm{O}$ \\
\hline BGH 8310 & Feira-Cacoal & $11^{\circ} 25^{\prime} 59.71^{\prime \prime} \mathrm{S} 61^{\circ} 27^{\prime} 50.97^{\prime \prime} \mathrm{O}$ & BGH 8295 & $\begin{array}{l}\text { Novo Horizonte } \\
\text { D'Oeste }\end{array}$ & $11^{\circ} 43^{\prime} 28.60^{\prime \prime} \mathrm{S} 62^{\circ} 02^{\prime} 32.02^{\prime \prime} \mathrm{O}$ \\
\hline BGH 8311 & Feira-Cacoal & $11^{\circ} 25^{\prime} 59.71^{\prime \prime} \mathrm{S} 61^{\circ} 27^{\prime} 50.97^{\prime \prime} \mathrm{O}$ & BGH 8318 & Rolim de Moura & $11^{\circ} 43^{\prime} 39.95^{\prime \prime} \mathrm{S} 61^{\circ} 47^{\prime} 47.38^{\prime \prime} \mathrm{O}$ \\
\hline BGH 8312 & Feira-Cacoal & $11^{\circ} 25^{\prime} 59.71^{\prime \prime} \mathrm{S} 61^{\circ} 27^{\prime} 50.97^{\prime \prime} \mathrm{O}$ & BGH 8323 & $\begin{array}{l}\text { Feira- Presidente } \\
\text { Médici }\end{array}$ & $11^{\circ} 10^{\prime} 5.96^{\prime \prime} \mathrm{S} 61^{\circ} 54^{\prime} 14.23^{\prime \prime} \mathrm{O}$ \\
\hline BGH 8313 & Feira-Cacoal & $11^{\circ} 25^{\prime} 59.71^{\prime \prime} \mathrm{S} 61^{\circ} 27^{\prime} 50.97^{\prime \prime} \mathrm{O}$ & BGH 8331 & $\begin{array}{l}\text { Feira- Pimenta } \\
\text { Bueno }\end{array}$ & $11^{\circ} 41^{\prime} 07.78^{\prime \prime} \mathrm{S} 61^{\circ} 10^{\prime} 07.93^{\prime \prime} \mathrm{O}$ \\
\hline BGH 8319 & Feira-Cacoal & $11^{\circ} 26^{\prime} 27.20^{\prime \prime} \mathrm{S} 61^{\circ} 26^{\prime} 41.03^{\prime \prime} \mathrm{O}$ & BGH 8332 & Feira- Ji-Paraná & $10^{\circ} 52^{\prime} 37.38^{\prime \prime} \mathrm{S} 61^{\circ} 57^{\prime} 07.47^{\prime \prime} \mathrm{O}$ \\
\hline BGH 8320 & Feira-Cacoal & $11^{\circ} 26^{\prime} 27.20^{\prime \prime} \mathrm{S} 61^{\circ} 26^{\prime} 41.03^{\prime \prime} \mathrm{O}$ & BGH 8334 & $\begin{array}{l}\text { Mercado- Porto } \\
\text { Velho }\end{array}$ & $8^{\circ} 45^{\prime} 54.14^{\prime \prime}$ S 63 54’34.30" O \\
\hline BGH 8321 & Feira-Cacoal & $11^{\circ} 26^{\prime} 27.20^{\prime \prime} \mathrm{S} 61^{\circ} 26^{\prime} 41.03^{\prime \prime} \mathrm{O}$ & BGH 8337 & $\begin{array}{l}\text { Mercado- Porto } \\
\text { Velho }\end{array}$ & $8^{\circ} 45^{\prime} 54.14^{\prime \prime} \mathrm{S} 63^{\circ} 54^{\prime} 34.30^{\prime \prime} \mathrm{O}$ \\
\hline BGH 8340 & Feira-Cacoal & $11^{\circ} 26^{\prime} 27.20^{\prime \prime} \mathrm{S} 61^{\circ} 26^{\prime} 41.03^{\prime \prime} \mathrm{O}$ & BGH 8341 & $\begin{array}{l}\text { Presidente } \\
\text { Médici } \\
\end{array}$ & $11^{\circ} 18^{\prime} 15.87^{\prime \prime} \mathrm{S} 61^{\circ} 46^{\prime} 59.54$ " O \\
\hline
\end{tabular}




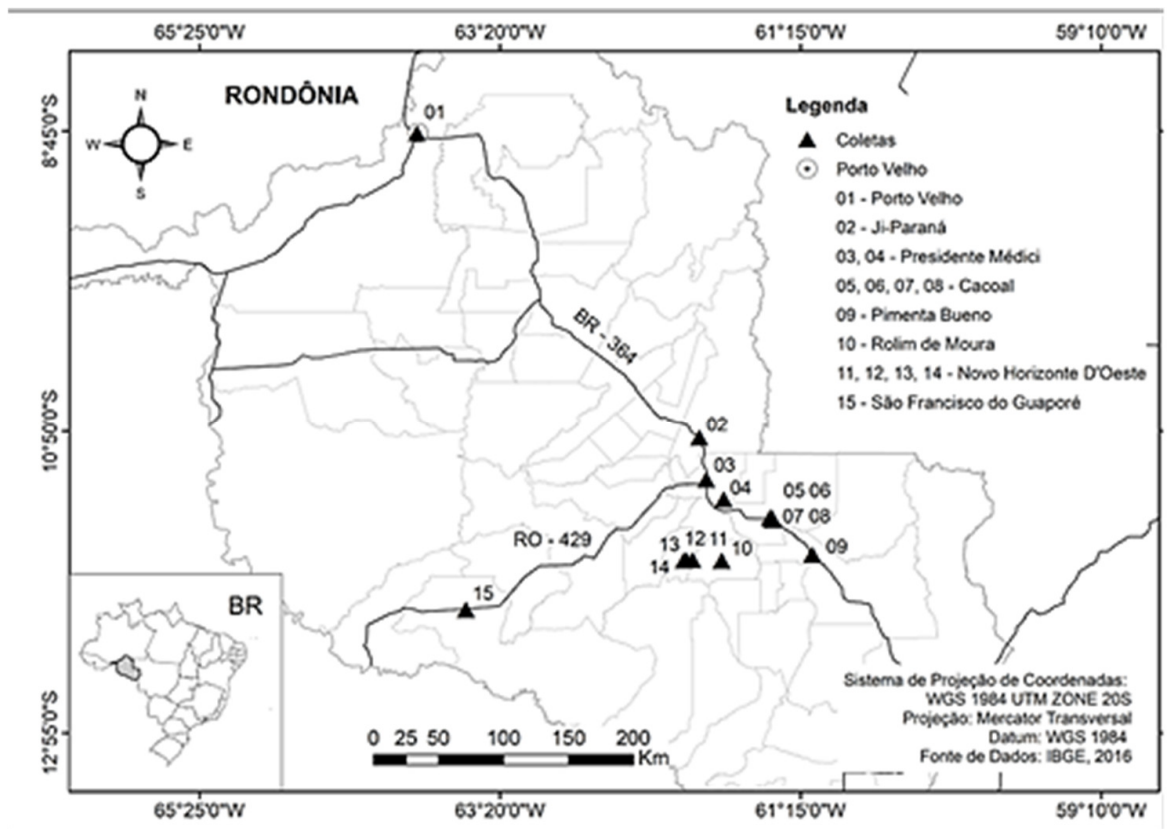

Figure 1. The location of the state of Rondônia in northern Brazil (left); cities of the state where the $C$. chinense genotypes were collected

\section{Experimental design and characteristics evaluated}

The seeds of the genotypes were obtained from the samples of fully ripe fruits weighing 250-500 g of fruits. After extraction of the seed samples, they were subjected to drying, identification, and storage at $4{ }^{\circ} \mathrm{C}$ until sowing.

The experiment was grown between July 2017 and September 2018 at the Experimental Unit "Horta Velha", in the Department of Plant Science, Federal University of Viçosa, Viçosa-MG (latitude: $20^{\circ} 45^{\prime}$ S, longitude: $42^{\circ} 54^{\prime} \mathrm{W}$; elevation: $648 \mathrm{~m}$ ).

The seedlings were produced in a 128 -cell polyethylene tray filled with a commercial substrate, which were transplanted to pots after 60 days, where they remained in a protected environment thereafter.

The experimental design used to evaluate the germplasm was completely randomized and as per the following statistical model:

Where,

$$
Y i j=T i+\mu+\varepsilon i j
$$

Yij corresponds to the observed value for a variable under study regarding the ith treatment in the ith repetition;

$T_{\mathbf{i}}$ corresponds to the effect of the ith treatment, which is considered as a random effect;

$\mu$ corresponds to the general average and;

$\varepsilon_{\mathrm{ij}}$ corresponds to the effect of the random error associated with the observation of order ij.

Each treatment consisted of 5 repetitions; each plot consisted of a plant kept in a 10-1 pot with soil.

For the characterization and evaluation of the accessions, we used 26 descriptors, as recommended by the IPGRI (1995) in the current Biodiversity International. The descriptors comprised the following agronomic and chemical-nutritional descriptors:

\section{$\underline{\text { Agronomic }}$}

Plant height (PH cm); canopy diameter (CD, cm); leaf length (LL, cm); leaf width (LW, cm); number of flowers per axilla (NFA); corolla length (CL, mm); anther length (AL, $\mathrm{mm})$; fruit length and diameter (FL and $\mathrm{FD}, \mathrm{mm}$ ); fruit peduncle length (FPL, $\mathrm{mm}$ ); pericarp thickness (PT, $\mathrm{mm})$; number of fruit locules (NFL); 
number of seeds per fruit (NSF); weight of 1000 seeds (WTS, g); total fruit production (TFP, g); number of fruits per plant (NFP).

\section{Chemical-nutritional}

The color determination of ripe fruits, performed at the commercial harvesting point, was performed using the Color Reader CR-10 Konica Minolta colorimeter. The results were interpreted by the CIELAB System using the coordinates $\mathrm{L}^{*}, \mathrm{a}^{*}$, and $\mathrm{b}^{*}$. From the mean values of $\mathrm{a}^{*}$ and $\mathrm{b}^{*}$, we calculated, according to the following equations, the estimates of saturation (Chroma, $\mathrm{C}^{*}$ ) and angle Hue (chromatic $\mathrm{h}^{*}$ ) (Itle and Kabelka, 2009):

$C^{*}=\sqrt{ } a^{* 2}+b^{* 2}$

$H$ ue $=\tan -1\left(b^{*} / a^{*}\right)$

Nutritional-chemical analyzes were performed from ripe fruit samples. For titratable acidity (TA) analysis, $5 \mathrm{~g}$ of ground fruit pulp was added to a 100-ml-volumetric flask containing distilled water, and $10 \mathrm{ml}$ of this solution was pipetted into an Erlenmeyer flask, to which 2 drops of 1\% phenolphthalein were added. The mixture was titrated with $0.005 \mathrm{~mol} \mathrm{NaOH} \mathrm{l}^{-1}$, according to the Adolfo Lutz Institute (2008), and the results were expressed as \% citric acid.

The $\mathrm{pH}$ was determined through direct reading using a digital pedometer (DIGIMED model DM 22) previously calibrated with $\mathrm{pH}-6.86$ buffer solutions and then with a $\mathrm{pH}-4.01$ buffer solution at $25^{\circ} \mathrm{C}$. For this analysis, we used $200 \mathrm{~g}$ of the ground fruit pulp.

The analysis of soluble solids ( ${ }^{\circ}$ Brix $)$ was performed using a sample of fruit juice obtained via maceration. This sample was placed on the luminous surface of a digital refractometer for reading, and the values were expressed in Brix degree. The estimation of the ratio was obtained from the relationship between soluble solids values and titratable acidity (SS/TA) according to the Adolfo Lutz Institute Analytical Standards (2008), and the results were expressed in absolute numbers.

For the analysis of vitamin C (CV) content, samples of $1 \mathrm{~g}$ seedless fruits were weighed on a $1200 \mathrm{~g}$ analytical balance with 0.1-g precision (Bel Engineering M1003). These samples were subsequently triturated in $20 \mathrm{ml}$ of $1 \%$ oxalic acid (Sigma-Aldrich Missouri USA) using polytron until complete homogenization. For the quantification, $1 \mathrm{ml}$ of the sample was added to an Erlenmeyer flask containing $25 \mathrm{ml}$ of $1 \%$ oxalic acid. Ascorbic acid content was determined using the modified Tillmans method by titrating 2,6dichlorophenolindophenol sodium (DFI; 0.02\%; Sigma-Aldrich, Missouri, USA) (AOAC, 2012). For titration, L-ascorbic acid PA (Sigma-Aldrich Missouri, USA) was used as the standard, and the results of vitamin $\mathrm{C}$ contents (expressed in $\mathrm{mg}$ ascorbic acid $100 \mathrm{~g}^{-1}$ sample) according to the formula proposed by the Ministry of Agriculture Livestock and Supply (MAPA, 2013).

\section{Statistical analysis}

For data analysis, a univariate analysis was initially performed to obtain the estimate and significance of the mean squares of the evaluated characteristics as well as to obtain the genetic-statistical parameters of the same characteristics. For the mean test, we adopted the Dunnet test at $5 \%$ probability, aiming at comparing the means of accessions with the checks.

Genetic diversity among the accessions was analyzed by Unweighted Pair-group Method Using Arithmetic Averages (UPGMA) based on the generalized distance of Mahalanobis, as presented by Cruz et al. (2011).

The ideal number of groups formed in the UPGMA hierarchical method was determined according to the Mojena's criterion (Mojena, 1977). This procedure is based on the relative size of merger levels in the dendogram, which is used to select the number of groups in stage $j$ that first satisfies the following inequality: $\alpha j>\theta k$, where $\alpha j$ is the value of distances from the fusion levels corresponding to stage $j(j=1,2, \ldots, n)$ and $\theta k$ is the cut off reference value, expressed as $\theta \mathrm{k}=\alpha^{\wedge}+\mathrm{k} \sigma^{\hat{\alpha}} \alpha$, where $\alpha$ and $\alpha \sigma^{\hat{\alpha}} \alpha$ are, respectively, non-biased estimates of the mean and standard deviation of $\alpha$ values and $\mathrm{k}$ is a constant. For the definition of the number of groups 
to be formed, the cutoff point based on the criterion $\mathrm{k}=1.0$ was used according to the methodology of Milligan and Cooper (1985).

To verify the fit between the dissimilarity matrix and the dendogram, the cofenetic correlation coefficient (CCC) was obtained. Singh's method (1981) was used to evaluate the relative importance of the descriptors in relation to genetic divergence among the studied accessions. Statistical analyzes and diversity studies were performed using the Genes software (Cruz, 2013).

\section{Results}

\section{Mean squares, means, and genetic-statistical parameters}

In this study, we will highlight only the descriptors of greater agronomic and nutritional importance. The estimates for the mean squares of the evaluated characteristics ranged from 985.08 to 0.01 for the characteristics number of fruits per plant and titratable acidity of the fruit pulp, respectively (Table 2 ). The results obtained through analysis of variance (ANOVA) also revealed, through the $\mathrm{F}$ test, a significant difference for all the descriptors (Table 2).

The results obtained in this study showed a wide variation in the average evaluated characteristics, especially for the production (PF) and number of fruits (NFP), as well as for the vitamin C (VC) content of the fruit pulp (Table 2). The average for TFP ranged from 69.45 to $1.275 .27 \mathrm{~g}$ for BGH-8339 and BGH-8319 accessions, respectively, with an overall average of $629.9 \mathrm{~g}$. The overall average for NFP was 308.2, and the highest average for this treat corresponded to BGH-8290 access (721.00) and the lowest to BGH8296 access (97.00). The overall mean for the fruit pulp vitamin C content was $1107.41 \mathrm{mg} / 100 \mathrm{~g}$ and the averages for this trait ranged from $734.37 \mathrm{mg} / 100 \mathrm{~g}$ for BGH8335to $1509.81 \mathrm{mg} / 100 \mathrm{~g}$ for BGH-8328.

The average for plant height $(\mathrm{PH})$, was $81.2 \mathrm{~cm}$, and the lowest mean for this trait corresponded to the BGH-8318 $(53.6 \mathrm{~cm})$ and the highest to the BGH-8310 $(124.2 \mathrm{~cm})$. The descriptors length, diameter, and thickness of the fruit also expressed variation, especially the first one, ranging from 7.8 (BGH-8318) to 85.4 $\mathrm{mm}$ (BGH-8331). The averages for the descriptor $\left(\mathrm{Cra}^{*}\right)$, corresponding to the contribution of red in fruit color, ranged from 7.8 (BGH-8288) to 59.7 (BGH-8325), and the overall mean for this trait was 43.5. The chemical descriptors of soluble solid of fruit pulp (SS), $\mathrm{pH}$, titratable acidity (TA), and the soluble solids/titratable acidity ratio (SS/TA) expressed variation, especially SS, which ranged from 5.7 to 13,8 for accessions BGH-8312 and BGH-8311, respectively (Table 2).

The evaluated characteristics expressed different estimates of phenotypic variance, and the highest estimates for this parameter corresponded to the descriptors PF, VC, and NFP. The lowest phenotypic variances corresponded to the chemical descriptors of fruits TA, $\mathrm{pH}, \mathrm{SS} / \mathrm{AT}$, and SS. The heritability estimates ranged from 21.6 to 98.6 for the SS/AT and CF descriptors, respectively. These estimates were considered high (>70.0) for all descriptors, except for $\mathrm{pH}$ (55.8) and SS/TA (21.6) (Table 2).

Regarding the coefficient of genetic variation (CVg \%), the descriptors DF (64.8) and FL (63.9) expressed the highest values for this parameter. The $\mathrm{CVg} / \mathrm{CVe}$ ratio was $>1$ unit for all descriptors, except for $\mathrm{pH}$. As observed in Table 2, most of the descriptors had low coefficients of variation, and slightly higher values for this parameter were observed only for FD, PF, and NFP. 
Table 2. Summary of analysis of variance and genetic-statistical parameters for the 13 agronomic descriptors and chemical-nutritional aspects of fruits used to characterize $C$. chinense germplasm from the Amazon region. UFV, Viçosa, 2019

\begin{tabular}{|c|c|c|c|c|c|c|c|c|c|c|c|c|c|}
\hline \multicolumn{10}{|c|}{ Mean squares } \\
\hline VF & PH & CD & FL & FD & PT & PF & NFP & Cra $^{*}$ & VC & SS & pH & TA & SS/TA \\
\hline Genotypes & $927.0^{* *}$ & $504.0^{* *}$ & $1.7^{* *}$ & $179.3^{* *}$ & $0.74^{* *}$ & $361.3^{* *}$ & $985.08^{* *}$ & $905.0^{* *}$ & $117.1^{* *}$ & $9.3^{* *}$ & $0.1^{*}$ & $0,01^{*}$ & $3.7^{* *}$ \\
\hline \multicolumn{10}{|c|}{ Parameters } \\
\hline Range & $53,0-$ & $35,33-$ & $7,8-$ & $7,1-$ & $0.8-$ & $69.4-$ & $97-721$ & $7,8-$ & $734,3-$ & $5,7-$ & $4,6-$ & $0,1-$ & $38,02-$ \\
& 124,2 & 97,75 & 85,4 & 32,5 & 2,6 & $1.275,2$ & & 59,7 & $1.509,8$ & 13,8 & 5,3 & 0,3 & 99,27 \\
\hline $\mathbf{M}$ & 81.2 & 72.8 & 31.0 & 15.9 & 1.7 & 629.9 & 308.2 & 43.5 & 1107 & 9,3 & 4.9 & 0.2 & 60.6 \\
\hline$\sigma_{\boldsymbol{p}}$ & 217.1 & 15.9 & 403.5 & 28.6 & 0.2 & 84646.5 & 23080.1 & 212.1 & 27444.3 & 2.2 & 0.03 & 0.00 & 0.9 \\
\hline $\boldsymbol{h}^{2}$ & 92.6 & 86.5 & 98.6 & 90.3 & 90.4 & 95.1 & 95.9 & 95.5 & 92.4 & 93.1 & 55.8 & 94.6 & 91.6 \\
\hline CVg \% & 17.3 & 13.8 & 63.9 & 64.8 & 22.8 & 44.9 & 48.7 & 32.2 & 14.4 & 15.4 & 2.6 & 28.07 & 24.7 \\
\hline CVg/CVe & 1.7 & 1.2 & 4.1 & 1.5 & 1.5 & 2.1 & 2.3 & 2.2 & 1.7 & 1.8 & 0.5 & 2.03 & 1.6 \\
\hline CV (\%) & 10.2 & 11.3 & 15.8 & 44.3 & 15.3 & 21.0 & 20.6 & 14.7 & 8.5 & 8.7 & 4.8 & 13.8 & 6.8 \\
\hline
\end{tabular}

VF: variation factor; PH: plant height $(\mathrm{cm})$; CD: canopy diameter $(\mathrm{cm})$; FL: fruit Length $(\mathrm{mm})$; FD: fruit diameter $(\mathrm{mm})$; PT: pericarp thickness $(\mathrm{mm})$; PF: total production of fruits production; NFP: number of fruits per plant; Colorimetric parameter Cra *: contribution of red; VC: vitamin C; SS: soluble solids; $\mathrm{pH}$ : hydrogen potential; TA: titratable acidity and SS/AT: ration between soluble solid and titratable acidity. $\mu$ : overall mean; $\sigma_{\mathrm{p}}$ : phenotypic variance $\mathrm{h}^{2}$ : heritability; $\mathrm{CVg} \%$ : genotypic coefficient of variance; $\mathrm{CVg} / \mathrm{CVe}$ : relation of the genotypic coefficient of variance and the environmental variance coefficient; $\mathrm{CV}(\%)$ : coefficient of variation. ${ }^{* *}$, * Significant at 1 and $5 \%$ probability, respectively, by the $\mathrm{F}$ test.

\section{Average test}

By comparing the averages by Dunnett's test at $5 \%$ of probability (Table 3 ), it was found that the average of most accessions differed from the average of the checks (Table 3).

Table 3. Dunnett's mean test between the 53 accessions of $C$. chinense from the Amazon region and the 2 checks for agronomic descriptors and chemical-nutritional aspects of fruits. UFV, Viçosa, 2019

\begin{tabular}{|c|c|c|c|c|c|c|c|c|c|c|c|c|c|}
\hline atments & $\mathrm{PH}$ & CD & FL & FD & $\begin{array}{l}\text { PT } \\
\text { EP }\end{array}$ & NFP & PF & $\mathrm{Cra}^{*}$ & VC & SS & $\mathrm{pH}$ & TA & SS/TA \\
\hline 8287 & $3.0 \mathrm{~b}$ & $.0 \mathrm{ab}$ & 53.2 & $5.5 \mathrm{ab}$ & $2.0 \mathrm{ab}$ & $352.0 \mathrm{ab}$ & 1191.0 & 4.2 & $066.0 \mathrm{ab}$ & $7.5 \mathrm{ab}$ & $4.9 \mathrm{ab}$ & $.12^{\mathrm{a}}$ & $4.3 \mathrm{ab}$ \\
\hline GH 8288 & 12.0 & $63.0 \mathrm{~b}$ & 45.1 & 22.1 & $8 \mathrm{ab}$ & 133.0 & 657.0ab & 7.8 & 13.0ab & $7.1 \mathrm{~b}$ & $4.7 \mathrm{ab}$ & $15 \mathrm{ab}$ & $8.5 \mathrm{ab}$ \\
\hline BGH 8289 & $68.0 \mathrm{~b}$ & $66.0 \mathrm{ab}$ & $32.4 \mathrm{a}$ & $16.6 \mathrm{ab}$ & $1.8 \mathrm{ab}$ & $323.0 \mathrm{ab}$ & 849.0 & $42.8 \mathrm{~b}$ & $1264.0 \mathrm{~b}$ & $8.5 \mathrm{ab}$ & $4.8 \mathrm{ab}$ & $0.17 \mathrm{ab}$ & $50.1 \mathrm{ab}$ \\
\hline & $70.0 \mathrm{~b}$ & $63.0 \mathrm{~b}$ & 7 & $9.5 \mathrm{ab}$ & 1.1 & 721.0 & 387.0 & $59.4 a$ & $1200.0 \mathrm{ab}$ & $9.5 \mathrm{ab}$ & 5.0ab & 0.22 & $42.9 \mathrm{ab}$ \\
\hline & $69.0 \mathrm{~b}$ & $59.0 \mathrm{~b}$ & $15.2 \mathrm{~b}$ & $15.1 \mathrm{ab}$ & $1.5 \mathrm{ab}$ & $312.0 \mathrm{ab}$ & 404.0ab & 51.1ab & 1111.0ab & $8.5 \mathrm{ab}$ & $4.7 \mathrm{ab}$ & 0.22 & $39.8 \mathrm{ab}$ \\
\hline BGH 8292 & $62.0 \mathrm{~b}$ & $61.0 \mathrm{~b}$ & $23.1 \mathrm{ab}$ & $13.4 \mathrm{ab}$ & 1.3 & $356.0 \mathrm{ab}$ & 309.0 & $58.8 \mathrm{a}$ & $1260.0 \mathrm{~b}$ & 13.9 & 5.0ab & $0.15 \mathrm{ab}$ & 91.1 \\
\hline BGH 8293 & $70.0 \mathrm{~b}$ & $70.0 \mathrm{ab}$ & $22.9 \mathrm{ab}$ & $12.6 \mathrm{ab}$ & 1.3 & $300.0 \mathrm{ab}$ & 383.0ab & $57.8 \mathrm{a}$ & $1223.0 \mathrm{~b}$ & 10.9 & 5.1ab & 0.11 & 95.0 \\
\hline 8294 & $76.0 \mathrm{a}$ & $71.0 \mathrm{ab}$ & 4.6 & $17.6 \mathrm{ab}$ & $2.0 \mathrm{ab}$ & 232.0 & 1148.0 & $43.7 \mathrm{~b}$ & $888.0 \mathrm{a}$ & $8.9 \mathrm{ab}$ & $4.9 \mathrm{ab}$ & 0.11 & 77.9 \\
\hline & $82.0 \mathrm{a}$ & $68.0 \mathrm{ab}$ & & $20.7 \mathrm{a}$ & 2.7 & 225.0 & $741.0 \mathrm{a}$ & $49.4 \mathrm{ab}$ & $1214.0 \mathrm{ab}$ & 8.0ab & 5.0ab & $0.12^{\mathrm{a}}$ & $67.4 a$ \\
\hline BGH 8296 & $64.0 \mathrm{~b}$ & $68.0 \mathrm{ab}$ & $31.7 \mathrm{a}$ & 32.6 & $1.9 \mathrm{ab}$ & 97.0 & 1032.0ab & $40.6 \mathrm{~b}$ & 1013.0ab & $7.2 \mathrm{~b}$ & 5.0ab & $0.13 \mathrm{ab}$ & $52.4 \mathrm{ab}$ \\
\hline BGH 8297 & $86.0 \mathrm{a}$ & $73.0 \mathrm{ab}$ & $14.9 \mathrm{~b}$ & $10.6 \mathrm{ab}$ & 1.1 & $513.0 \mathrm{~b}$ & 395.0ab & 20.7 & $1152.0 \mathrm{ab}$ & $9.6 \mathrm{a}$ & 5.0ab & $0.12 \mathrm{ab}$ & $67.2 \mathrm{a}$ \\
\hline BGH 8298 & $87.0 \mathrm{a}$ & $80.0 \mathrm{a}$ & 39.8 & $19.8 \mathrm{ab}$ & $1.9 \mathrm{ab}$ & 0 & 74 & $49.2 \mathrm{ab}$ & $4.0 \mathrm{ab}$ & 8.9ab & $5.0 \mathrm{ab}$ & 0.11 & 85.3 \\
\hline & 8 & 75 & & 2 & $a b$ & 185.0 & $865.0 \mathrm{a}$ & $44.9 \mathrm{ab}$ & 1063.0ab & $8.7 \mathrm{ab}$ & $5.0 \mathrm{ab}$ & 0.11 & $69.5 a$ \\
\hline BGH 8300 & $83.0 \mathrm{a}$ & $83.0 \mathrm{a}$ & 36.1 & 25.5 & $1.8 \mathrm{ab}$ & 190.0 & 1027.0 & $46.5 \mathrm{ab}$ & $901.0 \mathrm{a}$ & 6.5 & $4.7 \mathrm{ab}$ & $0.15 \mathrm{ab}$ & $43.1 \mathrm{ab}$ \\
\hline BGH 8301 & $70.0 \mathrm{~b}$ & $79.0 \mathrm{a}$ & $20.2 \mathrm{ab}$ & $14.2 \mathrm{ab}$ & $2.0 \mathrm{ab}$ & 408.0ab & 680.0ab & $54.0 \mathrm{a}$ & $900.0 \mathrm{a}$ & $8.4 \mathrm{ab}$ & $4.7 \mathrm{ab}$ & 0.22 & $38.8 \mathrm{~b}$ \\
\hline BGH 8302 & $78.0 \mathrm{a}$ & $75.0 \mathrm{ab}$ & $21.0 \mathrm{ab}$ & $17.4 \mathrm{ab}$ & 2.4 & $357.0 \mathrm{ab}$ & 773.0ab & 19.7 & 1084.0ab & $9.4 \mathrm{ab}$ & $4.9 \mathrm{ab}$ & $0.13 a b$ & $71.2 \mathrm{a}$ \\
\hline BGH 8303 & $77.0 \mathrm{a}$ & $68.0 \mathrm{ab}$ & 11.) & $10.4 \mathrm{ab}$ & $1.7 \mathrm{ab}$ & $440.0 \mathrm{ab}$ & 278.0 & $55.0 \mathrm{a}$ & 839.0 & $9.9 \mathrm{a}$ & $4.7 \mathrm{ab}$ & 0.24 & $40.0 \mathrm{ab}$ \\
\hline BGH 8304 & $85.0 \mathrm{a}$ & $81.0 \mathrm{a}$ & $14.2 \mathrm{~b}$ & $11.6 \mathrm{ab}$ & $1.3 \mathrm{~b}$ & 665.0 & 610.0ab & $52.7 \mathrm{a}$ & $1049.0 \mathrm{ab}$ & $9.6 \mathrm{a}$ & $4.6 \mathrm{ab}$ & $0.19 \mathrm{ab}$ & $50.1 \mathrm{ab}$ \\
\hline BGH 8305 & $78.0 \mathrm{a}$ & $75.0 \mathrm{ab}$ & 8.8 & $7.8 \mathrm{ab}$ & $2.1 \mathrm{ab}$ & $376.0 \mathrm{ab}$ & 267.0 & $57.2 \mathrm{a}$ & $1089.0 \mathrm{ab}$ & $9.5 \mathrm{ab}$ & $4.7 \mathrm{ab}$ & 0.23 & $40.6 \mathrm{ab}$ \\
\hline BGH 8306 & $99.0 \mathrm{a}$ & $81.0 \mathrm{a}$ & 10.3 & $9.0 \mathrm{ab}$ & $1.8 \mathrm{ab}$ & $466.0 \mathrm{ab}$ & 309.0 & $59.7 \mathrm{a}$ & 987.0ab & 10.8 & $4.8 \mathrm{ab}$ & $0.2 \mathrm{ab}$ & $54.0 \mathrm{ab}$ \\
\hline BGH 8307 & $77.0 \mathrm{a}$ & $76.0 \mathrm{ab}$ & $18.7 \mathrm{ab}$ & $13.0 \mathrm{ab}$ & $1.9 \mathrm{ab}$ & $344.0 \mathrm{ab}$ & 313.0 & $54.8 \mathrm{a}$ & $1162.0 \mathrm{ab}$ & $9.6 \mathrm{ab}$ & $4.7 \mathrm{ab}$ & $0.17 \mathrm{ab}$ & $55.6 \mathrm{ab}$ \\
\hline BGH 8308 & $72.0 \mathrm{a}$ & $72.0 \mathrm{ab}$ & 36.0 & 24.4 & $1.8 \mathrm{ab}$ & 113.0 & 563.0ab & $43.7 \mathrm{~b}$ & $1113.0 \mathrm{ab}$ & $7.5 \mathrm{ab}$ & $4.7 \mathrm{ab}$ & $0.16 \mathrm{ab}$ & $49.2 \mathrm{ab}$ \\
\hline BGH 8309 & $79.0 \mathrm{a}$ & $49.0 \mathrm{~b}$ & $15.8 \mathrm{~b}$ & $10.8 \mathrm{ab}$ & $1.4 \mathrm{~b}$ & $353.0 \mathrm{ab}$ & 315.0 & $54.4 a$ & $1219.0 \mathrm{~b}$ & $10.2 \mathrm{a}$ & $5.2 \mathrm{~b}$ & $0.17 \mathrm{ab}$ & $58.2 \mathrm{ab}$ \\
\hline
\end{tabular}


Santana SR et al. (2020). Not Bot Horti Agrobo 48(4):2198-2214

\begin{tabular}{|c|c|c|c|c|c|c|c|c|c|c|c|c|c|}
\hline BGH 8310 & 124.0 & $75.0 \mathrm{ab}$ & $14.9 \mathrm{~b}$ & $14.3 \mathrm{ab}$ & $1.7 \mathrm{ab}$ & $344.0 \mathrm{ab}$ & $365.0 \mathrm{~b}$ & $44.8 \mathrm{ab}$ & $1154.0 \mathrm{ab}$ & 11.0 & $4.8 \mathrm{ab}$ & $0.15 \mathrm{ab}$ & $72.3 \mathrm{a}$ \\
\hline BGH 8311 & $91.0 \mathrm{a}$ & $65.0 \mathrm{ab}$ & $18.8 \mathrm{ab}$ & $18.2 \mathrm{ab}$ & $1.4 \mathrm{~b}$ & $343.0 \mathrm{ab}$ & $582.0 \mathrm{ab}$ & $40.1 \mathrm{~b}$ & $1225.0 \mathrm{~b}$ & 1.3 & $4.7 \mathrm{ab}$ & $0.14 \mathrm{ab}$ & 94.9 \\
\hline BGH 8312 & $83.0 \mathrm{a}$ & $70.0 \mathrm{ab}$ & 12.1 & $12.2 \mathrm{ab}$ & $1.4 \mathrm{~b}$ & $476.0 \mathrm{ab}$ & $503.0 \mathrm{ab}$ & $53.9 \mathrm{a}$ & 1371.0 & 5.8 & $4.8 \mathrm{ab}$ & 0.11 & $49.0 \mathrm{ab}$ \\
\hline BGH 8313 & $81.0 \mathrm{a}$ & $68.0 \mathrm{ab}$ & 11.8 & $10.9 \mathrm{ab}$ & $1.6 \mathrm{ab}$ & $414.0 \mathrm{ab}$ & $328.0 \mathrm{~b}$ & $59.5 \mathrm{a}$ & 1338.0 & $10.1 \mathrm{a}$ & $5.0 \mathrm{ab}$ & 0.24 & $46.7 \mathrm{ab}$ \\
\hline BGH 8314 & $76.0 \mathrm{a}$ & $65.0 \mathrm{~b}$ & 66.0 & 24.9 & $1.6 \mathrm{ab}$ & 136.0 & 1217.0 & 21.6 & $1213.0 \mathrm{ab}$ & $7.7 \mathrm{ab}$ & $4.9 \mathrm{ab}$ & $0.12^{a}$ & $61.8 \mathrm{ab}$ \\
\hline BGH 8315 & $89.0 \mathrm{a}$ & $68.0 \mathrm{ab}$ & $26.0 \mathrm{ab}$ & $15.6 \mathrm{ab}$ & 2.5 & 243.0 & $708.0 \mathrm{ab}$ & $50.3 \mathrm{ab}$ & 1305.0 & $9.7 \mathrm{a}$ & $5.1 \mathrm{ab}$ & $0.14 \mathrm{ab}$ & $67.2 \mathrm{a}$ \\
\hline BGH 8316 & $75.0 \mathrm{a}$ & $73.0 \mathrm{ab}$ & 40.1 & $16.3 \mathrm{ab}$ & $1.8 \mathrm{ab}$ & 122.0 & $340.0 \mathrm{~b}$ & $54.3 \mathrm{a}$ & $1137.0 \mathrm{ab}$ & 11.2 & $4.8 \mathrm{ab}$ & $0.20 \mathrm{~b}$ & $56.4 \mathrm{ab}$ \\
\hline BGH 8317 & $82.0 \mathrm{a}$ & $71.0 \mathrm{ab}$ & $22.3 \mathrm{ab}$ & $14.7 \mathrm{ab}$ & $2.4 \mathrm{a}$ & 140.0 & 334.0 & $58.2 \mathrm{a}$ & 994.0 & 9.7 & $5.0 \mathrm{ab}$ & 0.24 & 40.1 \\
\hline BGH 8318 & $54.0 \mathrm{~b}$ & $48.0 \mathrm{~b}$ & 7.9 & $8.4 \mathrm{ab}$ & $13.0 \mathrm{~b}$ & $485.0 \mathrm{ab}$ & $361.0 \mathrm{~b}$ & $59.7 \mathrm{a}$ & $1205.0 \mathrm{ab}$ & 10.6 & $4.7 \mathrm{ab}$ & 0.26 & $40.2 \mathrm{a}$ \\
\hline BGH 8319 & $81.0 \mathrm{a}$ & $89.0 \mathrm{a}$ & 40.1 & 26.3 & $2.2 \mathrm{ab}$ & 184.0 & 1275.0 & $45.9 \mathrm{ab}$ & $962.0 \mathrm{ab}$ & $8.2 \mathrm{ab}$ & $4.8 \mathrm{ab}$ & $0.16 \mathrm{ab}$ & $50.2 \mathrm{ab}$ \\
\hline BGH 8320 & $88.0 \mathrm{a}$ & $81.0 \mathrm{a}$ & $30.4 \mathrm{ab}$ & $15.7 \mathrm{ab}$ & $1.6 \mathrm{ab}$ & 241.0 & $642.0 \mathrm{ab}$ & $49.5 \mathrm{ab}$ & $1119.0 \mathrm{ab}$ & 11.6 & $4.8 \mathrm{ab}$ & $0.15 \mathrm{ab}$ & 76.9 \\
\hline BGH 8321 & $80.0 \mathrm{a}$ & $72.0 \mathrm{ab}$ & 54.6 & $13.9 \mathrm{ab}$ & $1.6 \mathrm{ab}$ & 190.0 & $744.0 \mathrm{ab}$ & $49.5 \mathrm{ab}$ & $1117.0 \mathrm{ab}$ & 11.0 & $5.0 \mathrm{ab}$ & $0.14^{\mathrm{a}}$ & 89.1 \\
\hline BGH 8322 & $86.0 \mathrm{a}$ & $73.0 \mathrm{ab}$ & 65.1 & $15.5 \mathrm{ab}$ & $1.6 \mathrm{ab}$ & 160.0 & $690.0 \mathrm{ab}$ & 25.8 & 1341.0 & 10.6 & $5.1 \mathrm{ab}$ & $0.12^{\mathrm{a}}$ & 79.9 \\
\hline BGH 8323 & 103.0 & $89.0 \mathrm{a}$ & $15.6 \mathrm{~b}$ & $16.1 \mathrm{ab}$ & $1.3 \mathrm{~b}$ & $361.0 \mathrm{ab}$ & $426.0 \mathrm{ab}$ & 15.3 & 783.0 & $9.8 \mathrm{a}$ & $4.9 \mathrm{ab}$ & $0.17^{\mathrm{a}}$ & $57.9 \mathrm{ab}$ \\
\hline BGH 8324 & $77.0 \mathrm{a}$ & $70.0 \mathrm{ab}$ & 8.4 & $9.8 \mathrm{ab}$ & $1.4 \mathrm{~b}$ & 541.0 & 244.0 & $38.5 \mathrm{~b}$ & $1205.0 \mathrm{ab}$ & 12.3 & $4.7 \mathrm{ab}$ & 0.32 & $38.3 \mathrm{~b}$ \\
\hline BGH 8325 & $68.0 \mathrm{~b}$ & $70.0 \mathrm{ab}$ & $20.3 \mathrm{ab}$ & $12.2 \mathrm{ab}$ & 1.1 & $413.0 \mathrm{ab}$ & $388.0 \mathrm{ab}$ & $59.8 \mathrm{a}$ & $875.0 \mathrm{a}$ & $9.9 \mathrm{a}$ & $4.9 \mathrm{ab}$ & $0.19 \mathrm{ab}$ & $52.8 \mathrm{ab}$ \\
\hline BGH 8326 & 119.0 & $92.0 \mathrm{a}$ & $34.2 \mathrm{a}$ & $17.3 \mathrm{ab}$ & $1.5 \mathrm{ab}$ & 254.0 & $549.0 \mathrm{ab}$ & $41.1 \mathrm{~b}$ & $1147.0 \mathrm{ab}$ & $9.1 \mathrm{ab}$ & $4.9 \mathrm{ab}$ & $0.17 \mathrm{ab}$ & $52.5 \mathrm{ab}$ \\
\hline BGH 8327 & 103.0 & $94.0 \mathrm{a}$ & $19.1 \mathrm{ab}$ & $15.6 \mathrm{ab}$ & $2.4 \mathrm{a}$ & $285.0 \mathrm{ab}$ & $798.0 \mathrm{ab}$ & $48.2 \mathrm{ab}$ & 1328.0 & $8.6 \mathrm{ab}$ & $5.0 \mathrm{ab}$ & $0.15 \mathrm{ab}$ & $57.6 \mathrm{ab}$ \\
\hline BGH 8328 & $84.0 \mathrm{a}$ & $81.0 \mathrm{a}$ & $16.0 \mathrm{~b}$ & $14.8 \mathrm{ab}$ & $1.9 \mathrm{ab}$ & 180.0 & $351.0 \mathrm{~b}$ & $44.3 \mathrm{ab}$ & 1510.0 & 10.9 & $5.0 \mathrm{ab}$ & 0.11 & 100.0 \\
\hline BGH 8329 & $70.0 \mathrm{~b}$ & $91.0 \mathrm{a}$ & $33.8 \mathrm{a}$ & $21.7 \mathrm{a}$ & 2.5 & $329.0 \mathrm{ab}$ & 1142.0 & $46.6 \mathrm{ab}$ & $969.0 \mathrm{ab}$ & $8.4 \mathrm{ab}$ & $4.7 \mathrm{ab}$ & $0.13 \mathrm{ab}$ & $64.9 \mathrm{a}$ \\
\hline BGH 8330 & $70.0 \mathrm{~b}$ & $86.0 \mathrm{a}$ & 38.8 & $7.2 \mathrm{ab}$ & 0.8 & 618.0 & $718.0 \mathrm{ab}$ & 14.5 & $1200.0 \mathrm{ab}$ & $9.3 \mathrm{ab}$ & $5.3 \mathrm{ab}$ & $0.14 \mathrm{ab}$ & $66.4 \mathrm{a}$ \\
\hline BGH 8331 & $88.0 \mathrm{a}$ & $73.0 \mathrm{ab}$ & 85.5 & $13.2 \mathrm{ab}$ & $1.6 \mathrm{ab}$ & 163.0 & $635.0 \mathrm{ab}$ & $56.3 a$ & $1199.0 \mathrm{ab}$ & $9.7^{\mathrm{a}}$ & $5.0 \mathrm{ab}$ & $0.12^{\mathrm{a}}$ & 79.5 \\
\hline BGH 8332 & $95.0 \mathrm{a}$ & $76.0 \mathrm{ab}$ & 64.6 & $17.6 \mathrm{ab}$ & $2.2 \mathrm{ab}$ & 115.0 & $785.0 \mathrm{ab}$ & $51.2 \mathrm{ab}$ & $1143.0 \mathrm{ab}$ & $9.0 \mathrm{ab}$ & $5.0 \mathrm{ab}$ & $0.13^{\mathrm{a}}$ & $69.4 \mathrm{a}$ \\
\hline BGH 8333 & $84.0 \mathrm{a}$ & $75.0 \mathrm{ab}$ & 49.8 & $18.3 \mathrm{ab}$ & $1.8 \mathrm{ab}$ & 209.0 & $853.0 \mathrm{a}$ & $34.3 \mathrm{~b}$ & $956.0 \mathrm{ab}$ & $8.4 \mathrm{ab}$ & $4.8 \mathrm{ab}$ & $0.12^{\mathrm{a}}$ & $67.0 \mathrm{a}$ \\
\hline BGH 8334 & $53.0 \mathrm{~b}$ & $63.0 \mathrm{~b}$ & $13.8 \mathrm{~b}$ & $12.3 \mathrm{ab}$ & $1.4 \mathrm{~b}$ & 594.0 & $431.0 \mathrm{ab}$ & $55.5 \mathrm{a}$ & $1023.0 \mathrm{ab}$ & $8.0 \mathrm{ab}$ & $5.1 \mathrm{ab}$ & $0.13 \mathrm{ab}$ & $60.4 \mathrm{ab}$ \\
\hline BGH 8335 & $101.0 \mathrm{a}$ & $73.0 \mathrm{ab}$ & 12.5 & $14.2 \mathrm{ab}$ & $1.8 \mathrm{ab}$ & $335.0 \mathrm{ab}$ & $384.0 \mathrm{ab}$ & $56.2 \mathrm{a}$ & 734.0 & $8.9 \mathrm{ab}$ & $5.1 \mathrm{ab}$ & $0.15 \mathrm{ab}$ & $56.9 \mathrm{ab}$ \\
\hline BGH 8336 & 112.0 & 98.0 & $18.2 \mathrm{ab}$ & $19.5 \mathrm{ab}$ & $2.1 \mathrm{ab}$ & $369.0 \mathrm{ab}$ & 885.0 & $29.5 \mathrm{~b}$ & 844.0 & $8.1 \mathrm{ab}$ & $4.8 \mathrm{ab}$ & $0.14 \mathrm{ab}$ & $58.1 \mathrm{ab}$ \\
\hline BGH 8337 & $72.0 \mathrm{a}$ & $81.0 \mathrm{a}$ & 78.6 & $13.7 \mathrm{ab}$ & $1.9 \mathrm{ab}$ & 160.0 & $653.0 \mathrm{ab}$ & 13.0 & 1331.0 & $8.7 \mathrm{ab}$ & $4.5 \mathrm{ab}$ & $0.15 \mathrm{ab}$ & $56.3 \mathrm{ab}$ \\
\hline BGH 8338 & $74.0 \mathrm{a}$ & 35.0 & $16.8 \mathrm{~b}$ & $11.1 \mathrm{ab}$ & 1.3 & $370.0 \mathrm{ab}$ & $334.0 \mathrm{~b}$ & $56.6 \mathrm{a}$ & $1119.0 \mathrm{ab}$ & 10.7 & $5.1 \mathrm{ab}$ & $0.19 \mathrm{ab}$ & $55.6 \mathrm{ab}$ \\
\hline BGH 8339 & 110.0 & $63.0 \mathrm{~b}$ & $17.6 \mathrm{ab}$ & $9.1 \mathrm{ab}$ & 1.0 & 186.0 & 69.0 & $41.3 \mathrm{~b}$ & 1312.0 & 11.6 & $5.0 \mathrm{ab}$ & $0.16 \mathrm{ab}$ & $63.7 \mathrm{ab}$ \\
\hline \multicolumn{14}{|l|}{ Checks } \\
\hline BGH 8340 & $87.0 \mathrm{a}$ & $80.0 \mathrm{a}$ & $26.0 \mathrm{a}$ & $15.4 \mathrm{a}$ & $1.9 \mathrm{a}$ & $378.0 \mathrm{a}$ & $627.0 \mathrm{a}$ & $56.1 \mathrm{a}$ & $1041.0 \mathrm{a}$ & $9.0 \mathrm{a}$ & $4.7 \mathrm{a}$ & $0.16^{a}$ & $56.3^{a}$ \\
\hline BGH 8341 & $55.0 \mathrm{~b}$ & $62.0 \mathrm{~b}$ & $22.2 \mathrm{~b}$ & $13.4 \mathrm{~b}$ & $1.8 \mathrm{~b}$ & $416.0 \mathrm{~b}$ & $569.0 \mathrm{~b}$ & $39.8 \mathrm{~b}$ & $1112.0 \mathrm{~b}$ & $8.1 \mathrm{~b}$ & $4.9 \mathrm{~b}$ & $0.17 \mathrm{~b}$ & $47.3 \mathrm{~b}$ \\
\hline
\end{tabular}

PH: plant height $(\mathrm{cm})$; CD: canopy diameter $(\mathrm{cm})$; FL: fruit Length $(\mathrm{mm})$; FD: fruit diameter $(\mathrm{mm})$; PT: pericarp thickness (mm); NFP: number of fruits per plant; PF: total production of fruits production; Cra ${ }^{*}$ colorimetric parameter: contribution of red; VC: vitamin C; SS: soluble solids; $\mathrm{pH}$ : hydrogen potential; TA: titratable acidity and SS/AT: ration between soluble solid and titratable acidity. The averages followed by the same letters of the checks in the column do not differ from these at the $5 \%$ probability level

For the PH descriptor, 33 of the 53 accessions did not differ from the check BGH 8340 (commercially named as 'Biquinho vermelho') $(87.0 \mathrm{~cm})$, and 13 accessions did not differ from the other check BGH 8341 (commercially named as 'Biquinho amarelo') $(55.0 \mathrm{~cm}$ ). The accessions BGH-8288, BGH-8310, BGH-8323, BGH-8326, BGH-8327, BGH-8336, and BGH-8339 expressed the highest PHs, averaging higher than the both checks. For the descriptor canopy diameter $(\mathrm{CD})$, most of the accessions did not differ from the checks, except for BGH-8336 $(98.0 \mathrm{~cm})$ accession, which was higher than the 2 checks, and for the BGH-8338 accession $(35,0 \mathrm{~cm})$ with a lower average than that of the checks (Table 3 ).

Regarding the FL (Fruit Length) descriptor, 14 accessions did not differ from the average of both the checks, which expressed an average of $24.1 \mathrm{~mm}$. On the other hand, 17 accessions expressed averages higher than the check of highest average, 'Biquinho vermelho' $(26.0 \mathrm{~mm})$. Regarding the FD descriptor, most of the accessions $(n=43)$, did not differ from both the checks that expressed a mean DF of $14.4 \mathrm{~mm}$, while only 6 accessions expressed averages higher than the check of the highest average for this characteristic, 'Biquinho 
vermelho' $(15.4 \mathrm{~mm})$. Thirty-one accessions did not differ from the average of both the checks $(1.85 \mathrm{~mm})$ in relation to the PT descriptor. On the other hand, accessions BGH-8295, BGH-8302, BGH-8315, and BGH8329 outperformed the average of both the checks with respect to PT (Table 3).

Analyzing NFP (Number of fruits per plant) descriptor, it was observed that the accessions BGH-8290, BGH-8304, BGH-8324, BGH 8330, and BGH-8334 expressed averages higher than both of checks' average (397 fruits per plant), with an emphasis on BGH- 8290 (721 fruits per plant). In addition, regarding this descriptor, a considerable part of the accessions $(\mathrm{n}=24)$, did not differ from both the checks, who expressed a mean NFP of 397 (Table 3). Regarding the FP, it was observed that the accessions BGH-8287, BGH-BGH8289, BGH-8294, BGH-8314, BGH-8319, BGH-8329, and BGH-8336 expressed averages higher than the checks ( $598 \mathrm{~g}$ ), highlighting accession BGH-8314 with an average of 1,217.0 g. Twenty-six of the 53 accessions did not differ from both the checks that expressed a PF mean of $598 \mathrm{~g}$ (Table 3 ).

For the $\mathrm{Cra}^{*}$ descriptor, which corresponds to the numerical values for colors between green $\left(-\mathrm{a}^{*}\right)$ and red $\left(+a^{*}\right)$, most accessions expressed means equal to the check highest average for this characteristic, Biquinho Vermelho (56.1). For VC (Vitamin C), the accessions BGH-8312, BGH-8313, BGH-8315, BGH-8322, BGH-8327, BGH-8328, BGH-8337, and BGH-8339 (on average) expressed content of VC $25 \%$ higher than the average of the checks $(1,076.5 \mathrm{mg} .100 \mathrm{~g}-1)$. On the other hand, most of the accessions $(\mathrm{n}=31)$ did not differ from the average of both the checks in relation to VC (Table 3). It was observed that 12 accessions expressed higher means than the checks (8.55) in relation to the SS descriptor. On the other hand, 25 of the accessions did not differ from the average of the witnesses in relation to the SS descriptor.

The accession variation associated with $\mathrm{pH}$, most accessions did not differ from the average of the checks $(4,8)$. For the AT descriptor, 27 of the 53 accessions did not differ from the average of the witnesses $(0.16)$, and 6 accessions expressed lower averages than the checks with the lowest average for this characteristic, 'Biquinho vermelho' (0.16). For the SS/AT ratio, BGH-8292, BGH-8293, BGH-8294, BGH-8298, GGH8311, BGH-8320, BGH-8321, BGH-8328, and BGH- 8331 expressed averages higher than those of the checks (51.8), and most of the accessions $(n=29)$ did not differ from the checks' average (Table 3$)$.

Variability analysis based on agronomic characteristics and chemical-nutritional aspects of fruits

The clustering of the genotypes based on the UPGMA method resulted in the formation of 11 groups (Figure 2). Group I clustered the following 12 accessions: BGH 8332, BGH 8294, BGH 8333, BGH 8298, BGH 8299, BGH 8321, BGH 8287, BGH 8146, BGH 8329, BGH 8300, and BGH 8319. Group II and group V gathered 14 accessions, and these 2 were the largest groups. Group II clustered accessions BGH 8297 and BGH 8330. Group IV, VI, IX, X, and XI clustered only one accession BGH 8324, BGH 8341, BGH 8288, BGH 8223, and BGH 8325, respectively. Group VII clustered the accessions BGH 8327, BGH 8328, BGH 8311, BGH 8310, and BGH 8339, and in group VIII the accessions BGH 8331, BGH 8322, and BGH 8337. Group VII identified the BGH-8328 accession-the one found with the highest vitamin C content $(1510.0 \mathrm{mg}$ $100 \mathrm{~g}^{-1}$ ) (Figure 2).

The cophenetic correlation coefficient obtained between the dendrogram and the genetic distance matrix was 0.63 .

\section{Contribution of the descriptors to the divergence among accessions}

By the method of Singh (1981), it was observed that the descriptors that most contributed to the genetic divergence among accessions were the $\mathrm{FL}$ - fruit length (22.3\%), with an average of 7.8-85.4 mm (Table 4$)$. The NFP - number of fruits per plant contributed with (10.0\%), with values of $97-721$ fruits per plant, and the PF - total production of fruits contributed with (8.2\%), with values of 69.45-1,275 g (Table 4).

Descriptors with the smallest contribution to genetic variability included the CD - canopy diameter, FD - fruit diameter, PT - pericarp thickness, and the NSF - number of seeds per fruit, with an average contribution of $2.0 \%$ (Table 4 ). 


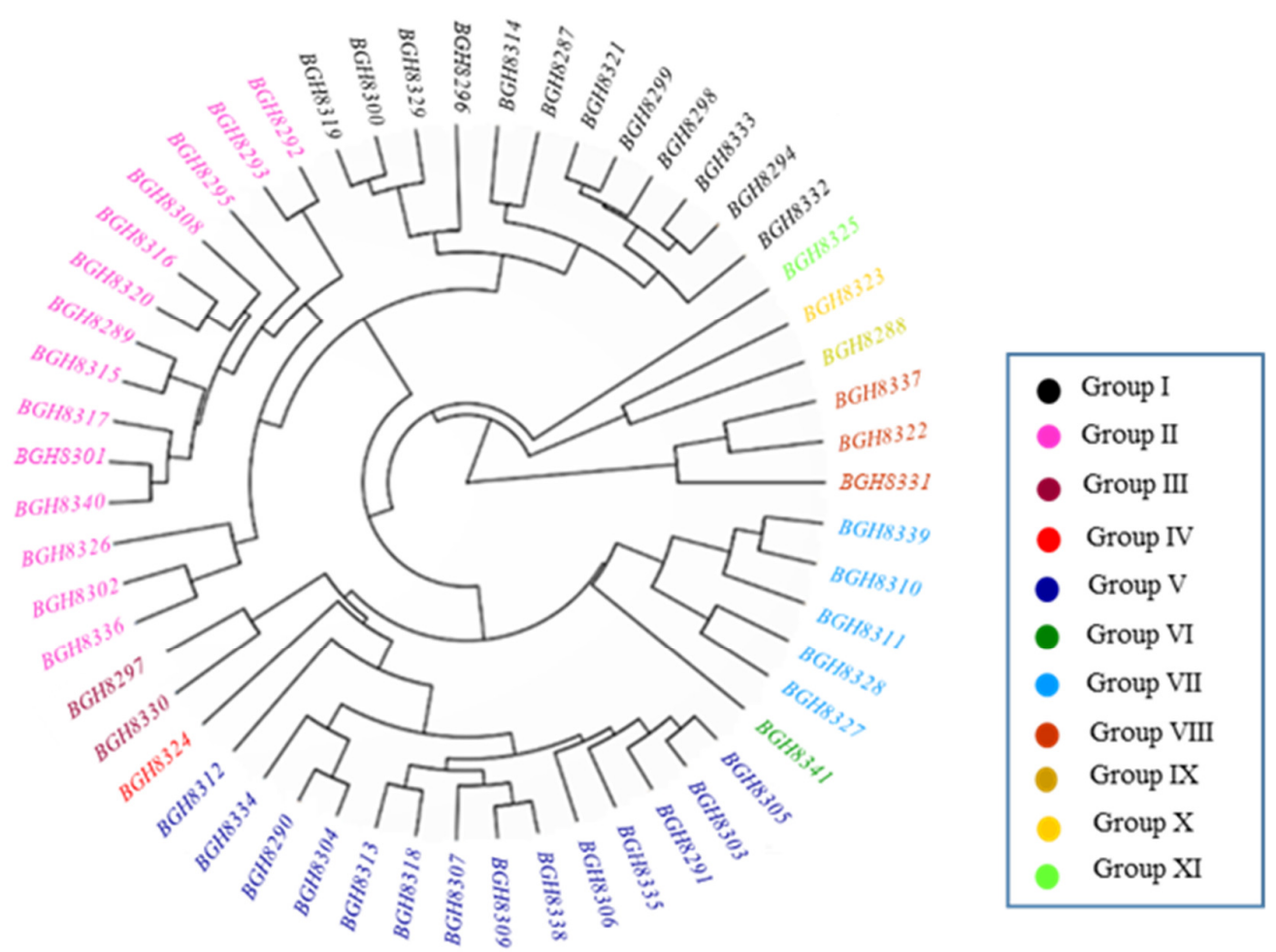

Figure 2. Dendogram obtained based on the data from agronomic descriptors and chemical-nutritional aspects of fruits of 55 accessions of $C$. chinense

Table 4. Relative contribution of agronomic and chemical-nutritional descriptors to the divergence of 55 accessions of $C$. chinense

\begin{tabular}{|c|c|c|c|}
\hline Traits & Contribution \% & Traits & Contribution \% \\
\hline PH & 5.1 & NSF & 3.4 \\
\hline CD & 2.4 & PF & 8.2 \\
\hline NFA & 3.6 & NFP & 10.0 \\
\hline CL & 5.9 & $\mathrm{a}^{*}$ & 6.6 \\
\hline AL & 4.2 & $\mathrm{~b}^{*}$ & 7.6 \\
\hline FL & 22.3 & VC & 4.6 \\
\hline FD & 2.0 & SS & 5.2 \\
\hline PT & 3.0 & TA & 6.1 \\
\hline
\end{tabular}

PH: plant height; CD: canopy diameter; NFA: number of flowers per armpit; CL: corolla length; AL: anther length; FL: fruit length; FD: fruit diameter; PT: pericarp thickness; NSF: number of seeds per fruit; PF: total fuit production; NFP: number of fruits per plant; $a^{*}$ : contribution of red color, $b^{*}$ : contribution of yellow color; VC: vitamin C; SS: soluble solids; TA: titratable acidity

\section{Discussion}

ANOVA analysis confirmed the wide genetic variability among the accessions. This was confirmed by the high estimates of phenotypic and genotypic variances for the descriptors, including $\mathrm{PH}$, fruit length, color parameter a ${ }^{*}$, total production of fruit, number of fruits per plant, and the vitamin $\mathrm{C}$ content. These results were expected, since these accessions had not been submitted to any selection process, suggesting that the $C$. 
chinense germplasm found in the Amazon region is a promising source for the improvement of this species' characteristics.

In the same direction, some studies have highlighted that the genetic variability present in a population is an essential condition for the beginning of a breeding program and should be explored to obtain genotypes with desirable characteristics (Santos et al., 2008; Galate et al., 2014). The average for the total fruit production obtained in this study $(629.9 \mathrm{~g})$ was slightly higher than the values reported elsewhere in the literature. When evaluating C. chinense accessions maintained at the Campinas Agronomic Institute, Domenico et al. (2012) reported an average value for this characteristic of $500 \mathrm{~g}$, while Lopes et al. (2016) reported an average value of $300 \mathrm{~g}$ in the evaluation of $C$. baccatum accessions.

The heritability estimates in this study were similar to those reported by Lannes (2005), who reported heritability estimates for FL, FD, and VC of $92.1,95.8$ and 78.2\%, respectively. Moreira et al. (2010) found values for NFP, FL and FD of 91.1, 89.1, and 93.6\%, respectively. On the other hand, Neto et al. (2014) found heritability estimate for $\mathrm{PH}$ of $92.9 \%$.

According to Rigon et al. (2012), the estimates of heritability, genotypic coefficient of variation, and the relationship between the genotypic and environmental coefficient of variation are important information in elucidating the genetic variability of a given population. Thus, parameters such as the genotypic coefficient of variation of a given trait informs the gain proportionality to the average in the case of selection, thus constituting an important parameter when determining the potential of a given population for breeding purposes. The relationship between the coefficient of genotypic variation and the coefficient of environmental variation with a value $>1$ unit indicates a favorable condition for selection. Thus, the selection processes can be successfully conducted in the germplasm evaluated in this study for traits such as PH, CD, FL, FD, PT, PF, Cra *, VC, and SS.

As for the coefficients of experimental variation, the results for total number of fruits per plant and the total fruit production found in this study were similar to those obtained by Moreira et al. (2010), who reported $\mathrm{CV}$ values for these characteristics of 20.5 and $23.0 \%$, respectively. In evaluating $C$. frutescens accessions, Rabelo et al. (2013) reported CV estimates of 12.9; 4.5; 10.7; and 14.8\% for the characteristic's vitamin C content, soluble solids, titratable acidity, and soluble solids/titratable acidity ratio, respectively. On the other hand, Neto et al. (2014) reported lower CV values for $\mathrm{PH}$ (7.7\%) and canopy diameter (3.8\%) than those found in the present study.

\section{Averages test}

The mean results observed for PH were similar to those recorded by Di Prado (2013), who reported amplitude for this characteristic of $53.3-95.04 \mathrm{~cm}$. PH is an important feature in defining the use classification of pepper cultivars, that is to determine whether the cultivars are best suited for landscape, ornamental, or production purposes. As per Rego et al. (2011), production gains in pepper can be achieved by cultivating tall plants.

For canopy diameter, values above and below the average of the two checks were observed only for accessions BGH 8336 and BGH 8338, respectively. According to Bento et al. (2007), canopy diameter is an important feature for growers in planning pepper cultivation, as this descriptor directly influences the determination of spacing to be used in planting.

The descriptors FL and FD are associated with the fruit quality of peppers when marketed freshly or preserved (Paulus et al., 2015). According to Lopes et al. (2016), larger fruits facilitate harvesting and increased productivity. Our results for FL were corroborated by Barroca et al. (2015) when evaluating the production of C. chinense $(70.83 \mathrm{~mm})$ and $C$. baccatum $(61.1 \mathrm{~mm})$. For the descriptor FD, these authors found the mean values of 13.2 and $17.2 \mathrm{~mm}$ for these 2 species, respectively. Ulhoa et al. (2017) estimated averages for this characteristic of 16.0-28.0 mm.

The descriptor PT is of commercial importance, mainly in the production of pulp for the processing of sauces. Thus, it is considered that thicker the pericarp, greater is the transport resistance, longer is the 
postharvest duration, and greater is the mass yield (Ulhoa et al., 2017). Notably, BGH 8315 accession, in addition to expressing thick pericarp, also expressed higher values than the checks for VC, which is interesting for both commercialization and exploitation of this trait in breeding programs. Moreover, the BGH 8295 accession expressed a higher average value for PT and NFP in comparison to the checks. The accession BGH 8329, in addition to the greater thickness of the pericarp in relation to the checks, expressed PF similar to that of the checks. Previous characterization studies of Amazonian pepper reported values for the pericarp thickness that is higher than that found in the present study. Costa et al. (2015), for example, found average values ranging from 3 to $4 \mathrm{~mm}$, while Pimenta (2015) obtained the average value of $2.9 \mathrm{~mm}$ for this characteristic.

According to Borem and Miranda (2009), productivity is one of the most important characteristics in plant breeding programs. The average value obtained for PF in this study was higher than that reported by Batista et al. (2014), which was an average of $842.9 \mathrm{~g}$. The average value found in this study was also higher than the value reported by Araújo (2013), who reported an average of $685.5 \mathrm{~g}$ for this characteristic. For the descriptor NFP, the mean values obtained in the present study were higher than those reported by Batista et al. (2014) and Araújo (2013), who reported an average number of fruits per plant of 205 and 685.5, respectively.

Fruit coloration in peppers is related to the presence of bioactive components in fruits such as carotenoids. Thus, the determination of the predominant color of fruits in this vegetable can help in the genetic breeding programs aimed at obtaining cultivars with fruits rich in carotenoids. In addition to the health benefits associated with the consumption of fruits with higher carotenoid contents, the presence of components such as carotenoids provide increased quality in fruit processing. In evaluating the coloration in pepper accessions, Carvalho et al. (2014) reported values for the parameter $\mathrm{a}^{*}$ of 5.9 to $33.9 \%$, which indicates the predominance of red color in fruits, which is similar to the result found in the present study.

Vitamin $\mathrm{C}$ has, among other nutritional aspects, significant antioxidant activity, and its consumption provides important health benefits. In the present study, we identified genotypes with extremely high content of vitamin C in fruits (up to $1510.0 \mathrm{mg} 100 \mathrm{~g}^{-1}$ ). According to TACO (2011), this value is much higher than that reported for species of the same genus of $C$. chinense and for fruits such as acerola, orange, and kiwi, which are excellent sources of vitamin $\mathrm{C}$. The high estimate of VC obtained in the present study is much above the estimates reported by previous studies. When assessing the $\mathrm{VC}$ content in the fruits of $C$. chinense in the

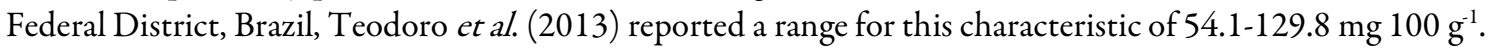
In assessing $123 \mathrm{C}$. baccatum accessions from the Asian Center for Plant Research and Development (AVRDC) in Taiwan, Perla et al. (2016) reported a variation for VC content of fruits of $2.5-50.4 \mathrm{mg} 100 \mathrm{~g}^{-1}$. On the other hand, when evaluating 216 C. chinense accessions from the United States Department of Agriculture/Agricultural Research Service (USDA/ARS), Jarret et al. (2009) reported values of up to 1466.0 $\mathrm{mg} 100 \mathrm{~g}^{-1}$ for vitamin $\mathrm{C}$ content in fruits.

The soluble solids values found in this study were close to those reported by Faria et al. (2013), Braga et al. (2013), and Borges et al. (2015) when evaluating the accessions of Capsicum sp., which obtained the values of $12.9,10.4$, and $11.0^{\circ} \mathrm{Brix}$, respectively. On the other hand, the present results were higher than those reported by Padilha (2017), who reported an average value for this characteristic of $6.7^{\circ}$ Brix. The soluble solids content is crucial for fruits when they are intended for fresh consumption, as these solids impart important organoleptic characteristics to fruits (Conti et al., 2002; Braga et al., 2013). Regarding pH, the results found in this study were lower than those observed by Braga et al. (2013), when evaluating the $C$. frutescens progenies in Ceará, which revealed an average value for this trait of 5.6. According to these authors, the $\mathrm{pH}$ measurement is an important parameter for the determination of a possible and rapid deterioration of the product owing to the presence and growth of microorganisms that are harmful to the health.

The estimates of TA of fruits obtained in this study $(0.1-0.3 \%)$ were much lower than those reported by similar studies. When performing the characterization of peppers in Roraima, the state of Brazil, Borges et al. (2015) observed a variation of 0.3 to $0.5 \%$ for this characteristic. Padilha (2017) also observed a variation for this characteristic of $1.05-1.7 \%$ when evaluating the species of the genus Capsicum. According to Reis et al. 
(2015), the lower levels of TA favor the conservation of fruits and byproducts. In addition, Santana et al. (2004) indicates that titratable acidity is important in characterizing the taste and aroma of fruits.

The relationship between soluble solids content and titratable acidity observed in the present study ranged from 38.02 to 99.27, which is higher than that reported by Rabelo et al. (2013), who reported lower values (31.07\%). Our results for soluble solid contents were also higher than those reported for this characteristic by Borges et al. (2015), who reported a variation of 19.4-51.3\%. According to Rabelo et al. (2013), the importance of soluble solid contents in fruits lies in the fact that this parameter suggests the state of balance between sugars and acids present in fruits.

Our results about the agronomic descriptors and chemical-nutritional aspects of $C$. chinense fruits confirm the high potential of this germplasm for production of these fruits specifically for fresh consumption and for the production of processed products.

\section{Variability analysis and contribution of descriptors to the divergence among accessions}

The UPGMA hierarchical method confirms that the $C$. chinense germplasm from the Brazilian Amazon and has a wide variability, which makes it a promising germplasm for application in programs aiming for the genetic improvement of this vegetable. According to Domiciano et al. (2015), the separation of accessions into distinct groups is important because it may indicate the existence of distinct gene polls that may be exploited in the future in controlled hybridizations as well as for reciprocal recurrent selection (SRR) schemes. In this study, the BGH 8324, BGH 8341, BGH 8288, BGH 8323, and BGH 8325 accessions were the most divergent, suggesting the possibility of combining these accessions with the other studied accessions to obtain a higher hybrid vigor.

The cophenetic correlation coefficient between the dendogram obtained in clustering of the genotypes and the distance matrix among these genotypes $(0.63)$ was $<0.7$, which is the minimum acceptable value for this parameter (Rohlf, 1970). On the other hand, Vaz Patto et al. (2004) showed that cophenetic correlation values $>0.56$ can be considered satisfactory as they portray distortions that are acceptable by clustering. In this study, we found distortion of only 13.8 .

With reference to the relative contribution of the descriptors to genetic divergence, our results were similar to those of Ferrão et al. (2011) and Rêgo et al. (2011), who also found that the characteristic FL was the major contributor to the genetic divergence among the pepper genotypes.

\section{Conclusions}

The germplasm of $C$. chinense evaluated in this study expressed a wide variability for agronomic characteristics and chemical-nutritional aspects of fruits, as observed by noting a significant difference for all these characteristics and the pattern of genotype grouping during the variability analysis.

Based on the UPGMA clustering, it was possible to identify the most promising accessions groups for use in breeding programs. For instance, group VII included BGH 8328-the accession as the highest mean for vitamin $\mathrm{C}$ content in fruits. This access is promising for use as a parent in pepper breeding programs that are aimed at increasing the vitamin $\mathrm{C}$ content in fruits.

The accessions BGH 8324, BGH 8341, BGH 8288, BGH 8323, and BGH 8325 are promising for use in pepper breeding programs that are aimed at genetic improvement of agronomic characteristics and chemicalnutritional aspects of fruits.

The germplasm of $C$. chinense from the Brazilian Amazon represents a valuable resource for the improvement of this species, and it is therefore important to collect this germplasm and conserve it in germplasm banks. 


\section{Authors' Contributions}

Conceptualization: Derly José Henriques da Silva. Data curation: Santina Rodrigues Santana. Investigation: Santina Rodrigues Santana, Ronaldo Silva Gomes, Renato Domiciano da Silva, and Paula Cristina Carvalho Lima. Software: Leonardo Lopes Bhering, Ronaldo Silva Gomes. Supervision: Derly José Henriques da Silva. Writing - original draft: Santina Rodrigues Santana. Writing - review \& editing: Santina Rodrigues Santana, Derly José Henriques da Silva. All authors read and approved the final manuscript.

\section{Acknowledgements}

We are thankful to the Coordenação de Aperfeiçoamento de Pessoal de Nível Superior (CAPES- Brasil) and especially to the National Council for Scientific and Technological Development (CNPq) for the funding support.

We would like to express our thanks to the Graduation Program on Plant Science of Universidade Federal de Viçosa for the support during the field trial and laboratory analysis of this study. We also thank all the professors and friends for their orientation and suggestions.

\section{Conflict of Interests}

The authors declare that there are no conflicts of interest related to this article.

\section{References}

AOAC (2012). Association of Official Analytical Chemistry. Official methods of analysis (19th ed), Gaithersburg.

Araujo CMM (2013). Genetic analysis in landraces of murupi pepper (Capsicum chinense Jacq.) of Amazonia. Dissertação, Instituto Nacional de Pesquisa da Amazônia.

Arruda S (2012). Rondônia climate. Retrieved 2020 November 8 from http://rondoniaemsala.blogspot.com/2011/12/clima-de-rondonia.html

Barroca MV, Bonomo R, Fernandes AA, Souza, JM (2015). Irrigation blades in the production components of 'de-odor' and 'dedo-de-moça' peppers. Agro@mbiente 9(3):243-250. https://dx.doi.org/10.18227/1982-8470ragro.v9i3.2342

Batista MRA, Silva Filho DF (2014). Morpho-agronomic characterization of non-pungent peppers of the genus Capsicum spp. from the Amazon. Agro@mbiente 8(2):204-211. http://dx.doi.org/10.18227/1982-8470ragro.v8i2.1337

Bento CS, Sudré CP, Rodrigues R, Riva EM, Pereira MG (2007). Qualitative and multicategorical descriptors in the estimation of phenotypic variability among chili pepper accessions. Scientia Agraria 8(2):147-154.

Borem A, Miranda GV (2009). Plant breeding. (1th ed), Viçosa, Minas Gerais.

Borges KM, Vilarinho LBO, Filho AAM, Morais BR, Rodrigues RNS (2015). Morpho-agronomic and physicochemical characterisation of the pepper for the State of Roraima. Agro@mbiente 9(3):292-299. https://dx.doi.org/10.18227/1982-8470ragro.v9i3.2766

Bosland PW, Votava EJ (2000). Peppers: vegetable and spice Capsicum. New York, Cabi.

Burle ML, Oliveira MSP (2010). Plant germplasm curators manual: morphological characterization. Brasília, Distrito Federal.

Braga TR, Pereira RA, Silveira MRS, Silva LR, Silva AR, Oliveira MMT (2013). Physical-chemistry characterization of chili peppers progenies grown in Paraipaba-CE. Revista Scientia Plena 9(5):2-6.

Carvalho SIC, Bianchetti LB, Ribeiro CSC, Lopes CA (2006). Capsicum peppers in Brazil (1th ed). Brasília, Distrito Federal. 
Carvalho AV, Aciel RA, Beckman JC, Poltronieri MC (2014). Characterization of Capsicum spp. during maturation. Embrapa Amazônia Oriental. https://ainfo.cnptia.embrapa.br/digital/bitstream/item/99243/1/BDP90.pdf

Chunab NC, Duch ES, Castilla LO, Burgos JIR (2011). Valuación de la calidad en la industrialización del chile habanero (Capsicum chinense) [Quality assessment in the industrialization of the habanero pepper (Capsicum chinense).]. Iberoamericana de Tecnología Postcosecha 12(2):222-226. https://www.redalyc.org/articulo.oa?id=81320900014

Conti JH, Minami K, Tavares FCA (2002). Production and quality of some cultivars of strawberry fruits in field experiments at Atibaia and Piracicaba, Brazil. Brazilian Horticulture 20(1):10-17. https://dx.doi.org/10.1590/S0102-05362002000100002

Costa LV, Bentes JLS, Lopes MTG, Alves SRM, Junior JV (2015). Morphological characterization of Amazon pepper accessions. Brazilian Horticulture 33(3):290-298.

Cruz CD, Ferreira FM, Pessoni LA (2011). Biometrics applied to the study of genetic diversity (1th ed). Minas Gerais.

Cruz CD, Regazzi AJ, Carneiro PCS (2012). Biometric models applied to genetic improvement (4th ed). Viçosa, Minas Gerais.

Cruz CD (2013). GENES - a software package for analysis in experimental statistics and quantitative genetics. Acta Scientiarum 35(3):271-276. https://doi.org/10.4025/actasciagron.v35i3.21251

Di Prado PRC (2013). Genetic parameters and selection gains in goat pepper (Capsicum chinense Jacq). MSc Dissertation, University of Goiás.

Domenico CI, Coutinho JP, Godoy HT, Melo AMT (2012). Agronomic traits and pungency of chilli pepper. Brazilian Horticulture 30(3):466-472. https://doi.org/10.1590/S0102-05362012000300018

Domiciano GP, Alves AA, Laviola BG, Conceição LDHCS (2015). Genetic parameters and diversity in progenies from Macaw Palm based on morphological and physiological traits. Rural Science 45(9):1599-1605. https://dx.doi.org/10.1590/0103-8478cr20140909

FAO (2016). Food and Agriculture Organization of the United Nations. Retrieved 2019 January 25 from http://www.fao.org/faostat/en/\#data/QC

Faria PN, Laia GA, Cardoso KA, Finger FL, Cecon PR (2013). Genetic variability of pepper (Capsicum chinense Jacq.) samples from a germoplasm bank: a case study. Agrarian Sciences 36(1):17-22.

Ferrão LFV, Cecon PR, Finger FL, Silva FF, Puiatti M (2011). Genetic divergence among sub-samples of pepper based on morpho-agronomic characters. Brazilian Horticulture 29(3):354-358. https://doi.org/10.1590/S010205362011000300016

Köppen W (1948). Climatology. Translation: Pedro RH. Gráfica Panamericana. Buenos Aires.

Galate RS, Mota MGC, Gaia JMD, Costa MSS (2014). Phenotypic distance among assai palm's mother plants (Euterpe oleracea Mart.) from Eastern Amazon. Semina: Agrarian Sciences 35(4):1667-1682. http://dx.doi.org/10.5433/1679-0359.2014v35n4p1667

Instituto Adolfo Lutz (2008). Physico-chemical methods for food analysis. (4th ed), São Paulo. https://wp.ufpel.edu.br/nutricaobromatologia/files/2013/07/NormasADOLFOLUTZ.pdf

IPGRI-International Plant Genetic Resources Institute (1995). Descriptors for Capsicum (Capsicum spp). Roma.

Itle RA, Kabelka EA (1997). Correlation between L a b color space values and carotenoids content in pumpkins and squash (Cucurbita spp.). Horticultural Science 122(4):594-598. https://doi.org/10.21273/HORTSCI.44.3.633

Jäger MA, AMAYA K (2013). Las cadenas de valor de los ajíes nativos de Perú. Compilación de los estudios realizados dentro del marco del proyecto "Rescate y Promoción de Ajíes Nativos en su Centro de Origen” para Perú [The value chains of the native peppers of Peru. Compilation of studies carried out within the framework of the project "Rescue and Promotion of Native Chili Peppers in their Center of Origin" for Peru]. Bioversity International. Cali.

Jarret SD, Berke T, Baldwin EA, Antonious GF (2009). Variability for free sugars and organic acids in Capsicum chinense. Chemical Biodiversity 6(2):138-145. https://doi.org/10.1002/cbdv.200800046

Lannes SD (2005). Diversity in Capsicum chinense: chemical, morphological and molecular analysis. PhD Thesis, University of Viçosa.

Lopes MAP, Gonçalves LD, Morais EG, Rezende CP, Vaz GHB (2016). Characterization of cumari pepper accessions of natural distribution for purposes of genetic improvement. Agrogeoambiental 8(4):105-115. http://dx.doi.org/10.18406/2316-1817v8n42016898 
MAPA (2013). Ministério da Agricultura, Pecuária e Abastecimento. Method for determining ascorbic acid. Handboo of methods of Analysis of Beverages and Vinegars. Retrieved 2018 December 15 from file://D:/Usuario/Downloads/N\%C3\%83O\%20ALCO\%C3\%93LICOS\%20\%2022\%20\%C3\%81cido\%20Asc\%C3\%B3rbico.pdf

Milligan GW, Cooper MC (1985). An examination of procedures for determining the number of clusters in a data set. Psychometrika 50(2):159-179. https://doi.org/10.1007/BF02294245

Mojena R (1977) Hierarchical grouping methods and stopping rules: an evaluation. The Computer Journal 20(4):359363. https://doi.org/10.1093/comjnl/20.4.359

Moreira SO, Rodrigues R, Araújo ML, Sudré CP, Riva-Souza EM (2010). Agronomic performance of recombinant chili pepper inbred lines in two cultivation systems. Science and Agrotechnology 34(4):886-891.

Moura WM, Casali VW, Cruz CD, Lima PC (1999). Genetic divergence of phosphorus nutritional efficiency in sweet pepper lines. Pesquisa Agropecuária Brasileira 34(2):217-224. https://doi.org/10.1590/S0100$204 X 1999000200010$

Neto JJS, Rêgo ER, Nascimento MF, Filho VALS, Neto JXA, Rêgo MM (2014). Variability in a base population of pepper (Capsicum annuum L.). Ceres 61(1):084-089. http://dx.doi.org/10.1590/S0034-737X2014000100011(2014)

Paulus D, Valmorbida R, Santin A, Toffoli E, Paulus, E (2015). Growth, yield and fruit quality of pepper (Capsicum annuum) at different spacings. Brazilian Horticulture 33(1):91-100. http://dx.doi.org/10.1590/S0102053620150000100001

Padilha HKM (2017). Genetic resources of peppers (Capsicum, Solanaceae): genetic diversity, resistance to anthracnose and production of specialized metabolites. PhD Thesis, University of Pelotas.

Perla V, Nadimi M, Hankins G, Reddy UK, Nimmakayala P, Alaparthi S, Ebert A (2016). Vitamin C and reducing sugars in the world collection of Capsicum baccatum L. genotypes. Food Chemistry 202:189-198. https://doi.org/10.1016/j.foodchem.2016.01.135

Pimenta S (2015). 'Carioca' and 'Uenf carioquinha': New pepper cultivars (Capsicum annuum var. annuum) resistant to bacterial spot. PhD Thesis, University of Norte Fluminense.

Pinto CMF, Pinto CLO, Donzeles SML (2013). Chemical, nutritional, pharmacological and medicinal properties and their potential for agribusiness. Sustainable Agriculture 3(2):108-120. https://docplayer.com.br/28910286Pimenta-capsicum-propriedades-quimicas-nutricionais-farmacologicas-e-medicinais-e-seu-potencial-para-oagronegocio-1.html

Reifschneider FJB (2000). Capsicum: peppers and peppers in Brazil. (1th ed), Brasília.

Rabelo BT, Pereira RCAS, Silva LR, Oliveira MMT (2013). Physico-chemical characterization of pepper (Capsicum frutescens L.) progênies. Revista de la Facultad de Agronomía 12(1):6-10.

Rêgo ER, Finger FL, Rêgo MM (2011). Production, genetics and breeding of peppers (Capsicum spp.). (1th ed), Recife.

Reis DR, Barbosa CMD, Silva FS, Porto AG, Soares EJO (2015). Biometric characteristics and physical-chemistry biquinho pepper variety. Scientific Center Know 11(21):454.

Rigon JPG, Capuani S, Cherubin MR, Rosa GM, Wastowski AD (2012). Agronomic performance and genetic dissimilarity unflower. Rural Science 42(11): 1954-1959.

Rodrigues R, Bento CS, Pimenta S, Sudré CP (2016). Pepper and Pepper Breeding. In: Nick C, Borem A (Eds). Improvement of vegetables. Viçosa, Minas Gerais pp 221-250.

Rohlf FJ (1970). Adaptive hierarchical clustering schemes. Systematic Zoology 18:58-82. https://doi.org/10.2307/2412027

Rufino JLS, Penteado DCS (2006). Economic importance, prospects and market potential for pepper. Agricultural Report 27(235).

Santana LRR, Matsuura FCAU, Cardoso RL (2004). Improved genotypes of papaya (Carica papaya L.): sensory and physico-chemical evaluation. Science and Food Technology 24(2):217-222. https://dx.doi.org/10.1590/S0101-20612004000200010

Santos CEM, Pissioni LLM, Morgado MAD, Cruz CD, Bruckner CH (2008). Strategies of selection in yellow passion fruit progenies for vigor and scab incidence. Brazilian Journal of

Fruit Growing 30(2):444-449. https://dx.doi.org/10.1590/S0100-29452008000200030

Singh D (1981). The relative importance of characters affecting genetic divergence. The Indian Journal of Genetic and Plant Breeding 41:237-245. 
TACO (2011). Table brazilian food composition table. UNICAMP. Retrieved 2018 September 18 from http://www.cfn.org.br/wp-ontent/uploads/2017/03/taco_4_edicao_ampliada_e_revisada.pdf

Teodoro AFP, Alves RBN, Ribeiro LB, Reis K, Reifschneider FJB, ... Agostini-Coata TS (2013). Vitamin C content in Habanero pepper accessions (Capsicum chinense). Brazilian Horticulture 31(1):59-62.

Ulhoa AB, Pereira TNS, Ribeiro CSC, Moita AW, Reifschneider FJB (2017). Development and morpho-agronomic characterization of yellow jalapeño pepper lines. Brazilian Horticulture 35(3):343-348. https://dx.doi.org/10.1590/s0102-053620170305

Vaz Patto MC, Satovic Z, Pêgo S, Fevereiro P (2004). Assessing the genetic diversity of Portuguese maize germoplasm using microsatellite markers. Euphytica 137(1):63-72.

https://doi.org/10.1023/B:EUPH.0000040503.48448.97
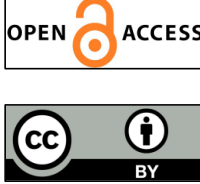

The journal offers free, immediate, and unrestricted access to peer-reviewed research and scholarly work. Users are allowed to read, download, copy, distribute, print, search, or link to the full texts of the articles, or use them for any other lawful purpose, without asking prior permission from the publisher or the author.

License - Articles published in Notulae Botanicae Horti Agrobotanici Cluj-Napoca are Open-Access, distributed under the terms and conditions of the Creative Commons Attribution (CC BY 4.0) License. (c) Articles by the authors; UASVM, Cluj-Napoca, Romania. The journal allows the author(s) to hold the copyright/to retain publishing rights without restriction. 